IZA DP No. 9148

Dismissal Disputes and Endogenous Sorting

Pietro Garibaldi

Gerard Pfann

June 2015 


\title{
Dismissal Disputes and Endogenous Sorting
}

\author{
Pietro Garibaldi \\ University of Torino, Collegio Carlo Alberto \\ and IZA \\ Gerard Pfann \\ Maastricht University, Stockholm University \\ and IZA
}

Discussion Paper No. 9148

June 2015

IZA
P.O. Box 7240
53072 Bonn
Germany

Phone: +49-228-3894-0

Fax: +49-228-3894-180

E-mail: iza@iza.org

Any opinions expressed here are those of the author(s) and not those of IZA. Research published in this series may include views on policy, but the institute itself takes no institutional policy positions. The IZA research network is committed to the IZA Guiding Principles of Research Integrity.

The Institute for the Study of Labor (IZA) in Bonn is a local and virtual international research center and a place of communication between science, politics and business. IZA is an independent nonprofit organization supported by Deutsche Post Foundation. The center is associated with the University of Bonn and offers a stimulating research environment through its international network, workshops and conferences, data service, project support, research visits and doctoral program. IZA engages in (i) original and internationally competitive research in all fields of labor economics, (ii) development of policy concepts, and (iii) dissemination of research results and concepts to the interested public.

IZA Discussion Papers often represent preliminary work and are circulated to encourage discussion. Citation of such a paper should account for its provisional character. A revised version may be available directly from the author. 


\section{ABSTRACT}

\section{Dismissal Disputes and Endogenous Sorting ${ }^{*}$}

Dismissal disputes occur mostly in recessions and often lead to long and costly contract termination procedures. This paper investigates how dispute procedures may affect the jobmatching process. First we present a simple accounting frame- work that corresponds with general dismissal legislation, but is sufficiently flexible to accommodate country-specific legislation. Detailed information from a sample of 2,191 disputes that occurred in the Netherlands between 2006 and 2009 is used to adjust the framework to Dutch institutional specificity. The resulting equilibrium matching model is solved to explain endogenous sorting between lengthy and costly firing procedures. The model also rationalizes the longevity of the dual Dutch model and its political resilience.

JEL Classification: E24, J08, J38, K31

Keywords: disputes, firing, legislation, sorting

Corresponding author:

Gerard Pfann

School of Business \& Economics

Maastricht University

6200 MD Maastricht

The Netherlands

E-mail: g.pfann@maastrichtuniversity.nl

\footnotetext{
* We gratefully acknowledge the dedicated supervision and indispensable contributions of Myrthe Frenk in collecting the data. Tamara Dekker and Eva Feron provided excellent research assistance. We thank the Swedish Institute for Social Research at the University of Stockholm for its hospitality. Feed-back from seminar participants in Barcelona Summer School 2015, Bonn, Stockholm, Seville, Toulouse 2015 SAM meeting, and Uppsala helped improving the paper. All errors are our own.
} 
"Fuller utilization of the concepts and hypotheses of economic theory (in a sense described below) as a part of the process of observation and measurement promises to be a shorter road, perhaps the only possible road, to the understanding of cyclical fluctuations."

Tjalling C. Koopmans, 1947 (p.162)

\section{Introduction}

For long, studies on disputes between a firm and its workers have focussed on the economics of strikes. ${ }^{1}$ But then, about two and a half decades ago, maybe because of Hicks' paradox, the focus of the study on the economic role of labor contracts shifted towards the role of severance pay in labor contracts and its effect on the level of employment (Lazear, 1990). Various international organizations, and the OECD in particular, have tried to summarize in simple indicators the degree and strictness of employment protection legislation. Even though these country indicators have been very popular in policy circles and in macroeconomic regressions, certainly they can not grasp the richness and complexity of job security provisions. Moreover, real life dismissal procedures are country specific and very complex. Perhaps surprisingly, few studies dig inside the details of these institutions.

A dismissal dispute is a difference between an employer and an employee that prevents agreement on work contract termination. One marked difference between a strike and a dismissal dispute is that "the incidence of strikes are positively related to general cyclical movements in the economy" (op. cit. Kennan (1986), p1133), whereas dismissal disputes happen more often in recessions. Disputed employer initiated separations often lead to

\footnotetext{
${ }^{1}$ Kennan (1986) gives an survey of the literature on the economics of strikes since 1880.
} 
costly and lengthy job termination processes. But how they affect the job-matching process precisely is unknown. Resolutions of dismissal disputes can have many forms, as emphasized by the law practice and by country specific legislation. Legal practice and country specific legislation typically distinguish between firm dominant (mostly economic) and worker dominant (mostly disciplinary) disputes. This provides a taxonomy that is often encoded in country specific laws. Inevitably, dismissal disputes are settled with the engagement of a third party or a court, that ultimately rules on the nature of the dispute and sets mandatory compensation.

Although many relevant and interesting questions may be asked, as of today the economics of dismissal disputes that adresses how firm worker pairs act, choose, and sort within the country specific legislation is at its infancy. How shall we model and account for different origins of dispute? How do different jobs sort among different disputes? How long and how costly are dismissal disputes? Do courts and related third party institutions respond differently to different types of dispute? These questions are barely touched upon in the existing literature, most likely because quantitative evidence on dismissal disputes is very difficult to assemble and very little information is available to the economics profession.

In the conviction that "there is no good measurement without theory", as argued prominently by Koopmans (1947), we first provide an economic taxonomy of dismissal disputes, using a simple static theory of firm worker matches. With the help of an accounting framework, dismissal disputes can then easily be classified as firm dominant, 
worker dominant, or both-to-blame. ${ }^{2}$ The latter category contains those cases where it is uncertain which party is responsible most for making the separation compulsory.

Armed with a well defined economic taxonomy, the paper looks at the key stylized facts of dismissal disputes in the Netherlands. The Dutch model of employment security is complex, as most European institutions are. Within the Netherlands, no employer initiated separation can take place without prior authorization, either from a labour court or from the Public Employment Service (PES), an institution that has been in place since the Nazi occupation of the Netherlands in the early nineteen forties. The unique feature of the Dutch model is that separations at the PES can take place with no severance payments, so that a non obvious and complex sorting mechanism takes place in the labor market. Empirically, the paper uses more than 2000 dismissal disputes that took place in the Netherlands between 2006 and 2009. This unique data set records detailed dispute level information on both the firm and the worker, including the wage, the penalty and duration of the disputes. And the data are also representative of the aggregate inflows into Dutch unemployment. The data show that disputes at the PES take longer but are much cheaper, and that the two institutions (the court and the PES) specialize in different types of dismissals. Court cases take less time, but results in more expensive separations. The reason for the shorter duration is that the majority of the cases handled by the court - in fact more than 80 percent of all 1,029 court cases in our data - are

\footnotetext{
${ }^{2}$ Both-to-blame: "Of course, both are to blame. Of course. You may always set that down as certain when you see two persons who have formerly been on good terms fall out with each other. For my part, I never take sides in these matters. I listen to what both have to say, and make due allowance for the wish of either party to make his or her own story appear most favorable. T.S. Arthur (1853): Home Lights and Shadows.
} 
experience-based situations where the employer and the employee are in agreement of the contract termination, but the termination of the contract requires formal approval. The court can then apply a formal but simple court formula to determine the height of the severance pay. In these pro forma cases the court just needs to produce a verdict that states the amount of severance pay, without the need to do much additional research on the details and reasonability of the contract termination. Moreover, large firms are more likely to settle disputes in the court and the demand for PES authorization increases relatively to court requests when economic activity slows down.

An important economic question is: "How does the sorting mechanism of dismissal disputes and severance pay exemption affect labor demand and unemployment?". In order to provide an answer to this question the paper proposes a Diamond Mortensen Pissarides (DMP) search model that highlights the trade off between separation at the PES and separation in court. Spelling out explicitly the time to fire, originally proposed by Garibaldi (1998), the model shows how different job worker pairs sort between a lengthy PES procedure and a shorter, but more expensive, court ruling. In equilibrium, all types of dismissals are observed by both institutions, but the model predicts that the court should specialize in cases where both parties are to blame, as data suggest. The economics of this sorting is straightforward. As the court provides an option to stop losses, firms are willing to undertake such costly procedure.

We extend the model to investigate whether or not the two institutions behave in a neutral way with respect to different types of dismissals. The model predicts that the PES would specialize into firm dominant dismissals as long as the PES increases its 
decision time for worker dominant cases. We go back to the data and find that such simple prediction is observed in the data. Indeed, both types of institutions behave differently for different cases, as if it were that the individual worker is protected more than the job.

Next, we analyze the fact that the PES as an institution survives fierce political attacks for a period of seventy years or more. A political economy exercise learns that once the PES is in place, the model predicts that if the median voter is employed in a good job, the elimination of the PES is vetoed by the majority of voters. Consequently, it is in the interest of most agents to keep it alive, although during recessions when unemployment rises the political basis of the PES is frailer. Finally, we also discuss whether the model can rationalize cyclical variations in PES ruling and whether or not it can say something about the fact that large firms are more likely to go to court. We argue that this is indeed the case, in particular when financial constraints are taken into account.

The economics of employment protection is at least 25 years old, and it is difficult to do justice to all contributions. Emerson (1988) was probably the first to summarize country specific legislation with simple indicators, a path that was extensively followed by the OECD's EPL Index. Lazear (1990) predicts the neutrality of severance payments when wages are flexible and was the first to use cross country regression to assess the impact of job security provisions on employment. Bentolila and Bertola (1990) critically assess the ambiguous effects of EPL on labor demand in a renowned application of Nickell's (1978) partial equilibrium model with linear adjustment costs under uncertainty. At the theoretical level modeling of employment protection is rather limited. The typical modeling tool for job security provisions is a simple firing tax, dissipated outside the 
match or paid to third parties (Mortensen and Milard, 1994). Garibaldi and Violante (2005) assess the difference between severance payments and firing taxes. Blanchard and Tirole (2008) provide a framework for the optimal design of employment protection institutions in the context of dual labour markets. Alvarez and Veracierto (2012) model temporary contracts as a special case of a separation tax.

Empirical research in the US estimates the social costs, in possibly lower employment, wages, and productivity of wrongful discharge laws and disability acts (eg. Acemoglu and Angrist (2001); Autor, Donahue and Schwab (2006)). In Europe, empirical research predominantly studies how employment protection legislation influences labor market participation and unemployment duration (cf. Boeri and Van Ours (2013)). When heterogeneity is taken into account the lay-off probability of each worker is found to be correlated negatively with this worker's expected firing costs (Pfann, 2006). Boeri, Garibaldi and Moen (2014) discuss the efficiency of severance payments when wages are back loaded and information is imperfect.

The paper proceeds as follows. Section 2 develops an accounting framework for classifying different types of dismissal disputes. The goal of this section is to derive an accounting framework consistent with economics reasoning. The paper's epigraph pays tribute to the idea that the best way to embark in measurements and observations of economic phenomena is to make full use of economics as a scientific discipline. In addition, the taxonomy we provide is also consistent with the law practice observed in most European countries and formally adopted in European legislative initiatives. ${ }^{3}$ Section

\footnotetext{
${ }^{3}$ In the Italian "Jobs act" approved by Parliament in November 2014, there is an explicit reference to firm dominant dismissals (economic in the Italian legislation) and worker dominant dismissals
} 
3 discusses in short the history and some of the specific aspects of Dutch labor market institutions and presents the information contained in a large data-set of individual dismissal conflicts that took place in the Netherlands between 2006 and 2009. The data records dispute level information on both the employer and the employee engaged in the controversy, including firm and worker characteristics, the reasons of the contract ending requests, the process durations, the decisions, and the associated costs. In Section 4 an equilibrium search model with endogenous sorting is presented that is coherent with the theoretical concepts of Section 2 as well as with the empirical results from Section 3. Section 5 presents relevant model extensions that include the possibility of institutional biases, aggregate productivity, and the role of financial constraints. This section also looks in more detail at the role of the Great Recession on the outcomes of the decision-making process of dismissal requests. Section 6 concludes.

\section{The Accounting of Disputes}

We consider a single firm output pair as a single job. The focus is on dismissal at the level of the job rather than at the level of the firm, and we think mainly of individual dismissals. The framework is static. We assume that a measure 1 of job is in place. There is no attempt to consider how these jobs were formed in the first place. Information is perfect.

The productivity of the job has two key components. A specific worker component $x$ and a specific firm component $y$. The $x$ component refers to the individual contribution (disciplinary in the Italian legislation). 
to the productivity of the job, including worker motivation and health condition. The $y$ component refers to firm specific characteristics, technological conditions, market and demand conditions that have nothing to do with the worker. We assume that total productivity in the job $z$ is the sum of the firm and worker component so that

$$
z=x+y
$$

In the space $x, y$ there is a job for every single point in the cartesian space $\Re^{2}$. The statistical properties of the job space and the underlying distribution is not particularly relevant at this stage, and we be outlined in Section $4 .{ }^{4}$

The wage that the worker gets from job is fixed at $w$ and it is independent of the productivity $x$ and $y$. We also assume that the worker outside option is a flow $f$ strictly lower than the wage. This implies that the worker enjoys a rent (or a net utility) from the job as

$$
U=w-f>0 \quad \forall\{x, y\} \in \Re^{2}
$$

Since $U$ is strictly positive, a worker will never want to severe a relationship.

The firm has no capital cost and it is only hiring this worker. The outside option of

\footnotetext{
${ }^{4}$ It is natural to think of $x$ as being drawn from a continuous random variable $X$ and $y$ being drawn from a random variable $Y$ that belong to joint continuous distribution $f(x, y)$ so that in the most general form we will have that

$$
F(x \leq a, y \leq b)=\int_{-\infty}^{b} \int_{-\infty}^{a} f(x, y) d x d y
$$

where $F$ is the joint cumulative distribution.
} 
the firm is zero. This implies that the firm profit $J(x, y)$ in a job of $\{x, y\}$ is

$$
J(x, y)=x+y-w
$$

From the profit function we can define the iso-profit contour as the combinations of $x, y$ that yield a given profit to the firm. In a $x, y$ space there are various properties of profit contour that are evident from equation (2). Isoprofits i) are downward sloping linear functions; ii) have a unit slope in absolute terms and iii) curves at the north east yield higher profit values to the firm.

Let us suppose that the firm can initiate a separation. The firm will destroy any job if $J(x, y)<0$. There exists a marginal iso-profit $J(x, y)=0$, such that

$$
y=-x+w
$$

Figure 1 plots the marginal good job contour.

Definition 1 The firm worker pair engage in a dismissal conflict each time $J(x, y)<0$ and $U(x, y)>0$

Result 2.1 Each job in a $(x, y)$ space below the marginal contour job represents a dismissal conflict.

This simple definition yields a natural classification of dismissal conflicts.

Definition 2 A dismissal conflict is firm dominant whenever $x>0$ and $y<0$ 
In terms of Figure 1, a firm dominant dismissal belongs to the fourth quadrant in the cartesian diagram below the marginal good job contour. In law jargon such a firm dominant dismissal is often referred to as an economic dismissal.

Definition 3 A dismissal conflict is worker dominant whenever $x<0$ and $y>0$

In terms of Figure 1, a worker dominant dismissal belongs to the second quadrant in the cartesian diagram below the marginal good job contour. In law jargon such a worker dominant dismissal is often referred to as a disciplinary dismissal.

Definition 4 In a dismissal conflict both parties are to blame when $x>0, y>0$ and $x+y<w$ or whenever $x<0$ and $y<0$.

In terms of Figure 1, a both-to-blame dismissal belongs to the first or third quadrant in the cartesian diagram below the marginal good job contour. We say that in a dismissal conflict the two parties are both-to-blame, because it is uncertain whether or not the lack of profitability can be contributed more to worker, to firm characteristics, or to both in equal proportions.

Note that the taxonomy we provide does not depend on the specific wage structure imposed. While it is natural to have a dismissal conflict when the worker and the firm do not agree on the job separation, the taxonomy survives in case of more efficient job separation. One can easily assume that the wage is a fraction $\omega$ of total productivity so that $w=\omega(x+y)$. Then the marginal contour would still be negatively sloped and would coincide with the 45 degree line. The model we present in section 4 is in line with privately efficient separations. 
Figure 1: The taxonomy of dismissal conflicts

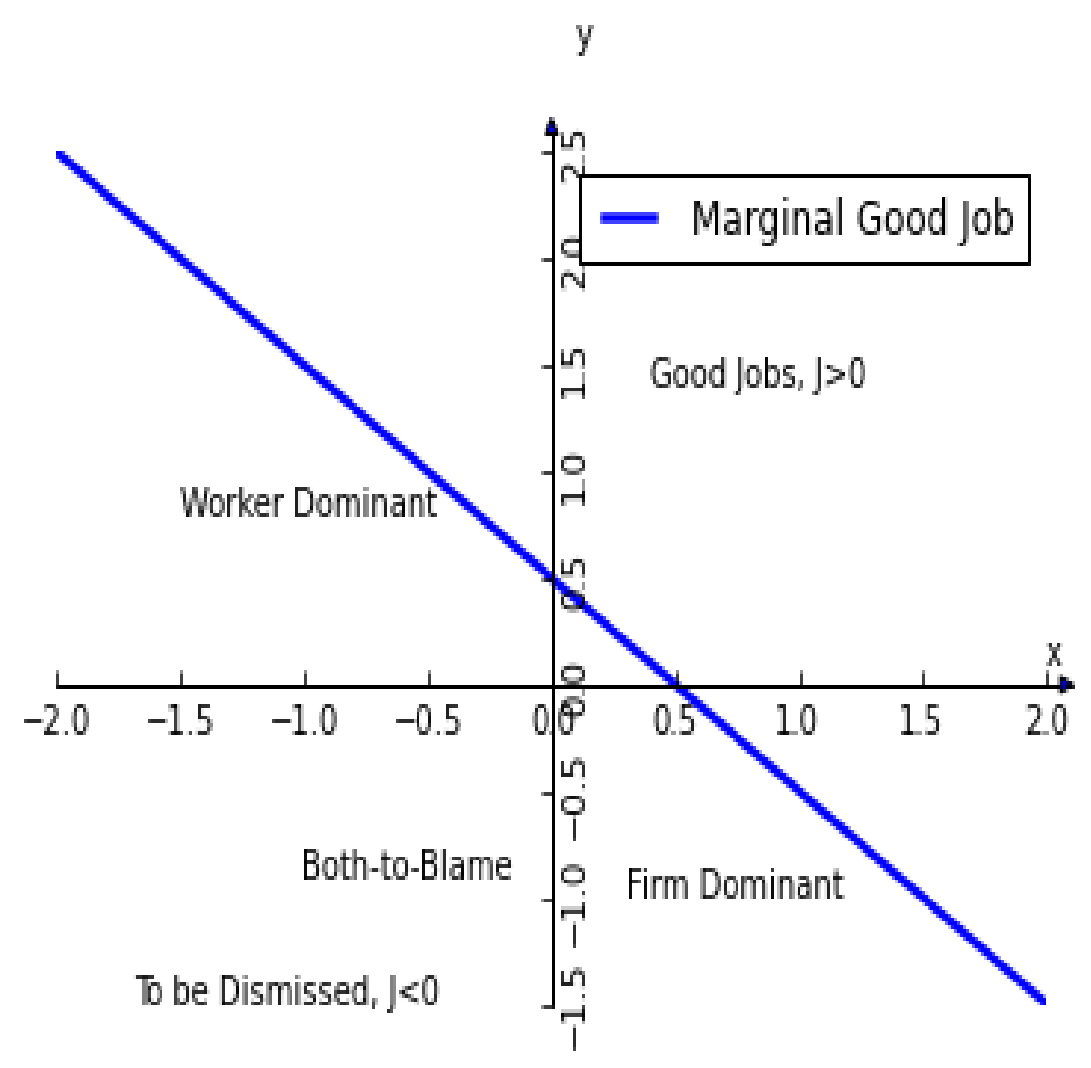




\section{Facts From Real Life Institutions}

Institutions for worker dismissal are often complex and unique. In the Netherlands, for example, firms are obliged to seek a priori permission to terminate an open-ended or permanent employment contract. Permission can be obtained from two established, but fundamentally different, organizations: the civil courts and the public employment service. The firm chooses the organization from which it will request a permission to terminate a contract on the basis of the grounds for dismissal. The two institutions coexists for almost 70 years. Despite fierce political debate the resilience of this duality in obtaining permission to fire permanent workers is amazing.

\subsection{Institutions}

\section{The Civil Court}

The introduction of the Civil Code of Law in 1838 is a milestone in the history of labor market legislation in the Netherlands. Inspired by the 1804 Code Napoléon, the Dutch civil code introduced a new national civil law that contained three articles regarding the employment relationship between an employer and an employee. Originally, rather than the employee these articles were all written to protect the employer. The introduction of the first legislative measures that aimed for the protection of the employee was not until 1909 when the Law on Employment Contracts was enacted. The basis of Dutch labor law is Chapter 7 of the Civil Code that is used by civil courts to deal with disputes and controversies on employment provisions. 


\section{The Public Employment Service (PES)}

On June $11^{\text {th }} 1940$ the German occupying forces enacted the First Enforcement Resolution (Eerste Uitvaardigingsbesluit), prohibiting any dismissal without prior permission of the Labor Inspectorate. A reasonable cause was required to obtain dismissal approval. The inspectorate checked the reasonability of the request. If a proposition for dismissal was judged unreasonable, permission to terminate the employment contract was not given. When the war had ended the Dutch government still held office in London. It upheld this resolution by the declaration of the Extraordinary Resolution Labor Relations of October $5^{\text {th }}, 1945$ (Buitengewoon Besluit Arbeidsverhoudingen 1945). The goal of the declaration was "to sustain and increase employment and to encourage production and productivity in order to stimulate the post WWII economic recovery."

At the time the country did not have a parliament to approve the 1945 resolution, and it obtained the status of a royal decree instead with the power of law. A network of public employment offices replaced the Labor Inspectorate. Not less than 30 local labor market regions are equipped with 130 local offices. These offices are responsible for observing the implementation and execution of the extraordinary resolution by order of the government..$^{5}$ On May $14^{\text {th }}, 1998$, the parliament approved the Repair Law of Flexibility and Security, turning the 1945 decree into formal law. The law states that an employer must ask for and needs to obtain permission for dismissal of a worker with a permanent contract. Without prior permission from a civil court or from the Public

\footnotetext{
${ }^{5}$ See also Chapter 7 in The Termination of the Contract of Employment. Antoine T.J.M. Jacobs (2004).
} 
Employment Service (PES) a dismissal is voidable. A decision by the PES can not be appealed, but it is possible to start a court procedure when the employer or the employee disagrees. A dismissal request that is granted by the PES comes without the requirement to pay severance.

\subsection{Empirical Facts}

Figure 2 shows all the requests for dismissals that have been submitted to the two institutions during the period 1998 through 2011. In the periods 2003-2004 and 2008-2009 at the onset of the Great Recession the number of dismissal requests to the public employment service increased relative to the number of requests to the civil court. The volumes of requests to both institutions are leading indicators for the unemployment rate. In recessions as well as during expansions firms are granted permission to dismiss workers and so avoid paying firing costs. This is consistent with the fact that job destruction occurs throughout the business cycle, though fewer firms decline in good times. In recessions, when more firms are hit by downward shocks, the number of dismissal requests directed to the civil courts and to the PES increase, but the increase in requests to the PES is higher. This fact hints at the policy's efficacy in bad times to lower firing costs.

\section{Individual Data on Dismissal Requests}

The number of dismissal cases filed each year to the civil courts are stored in an electronic database. Unfortunately, this database does not contain any detailed information on particular cases. All civil court files on individual dismissal cases are stored in archives 
Figure 2: Dismissal requests since 1998

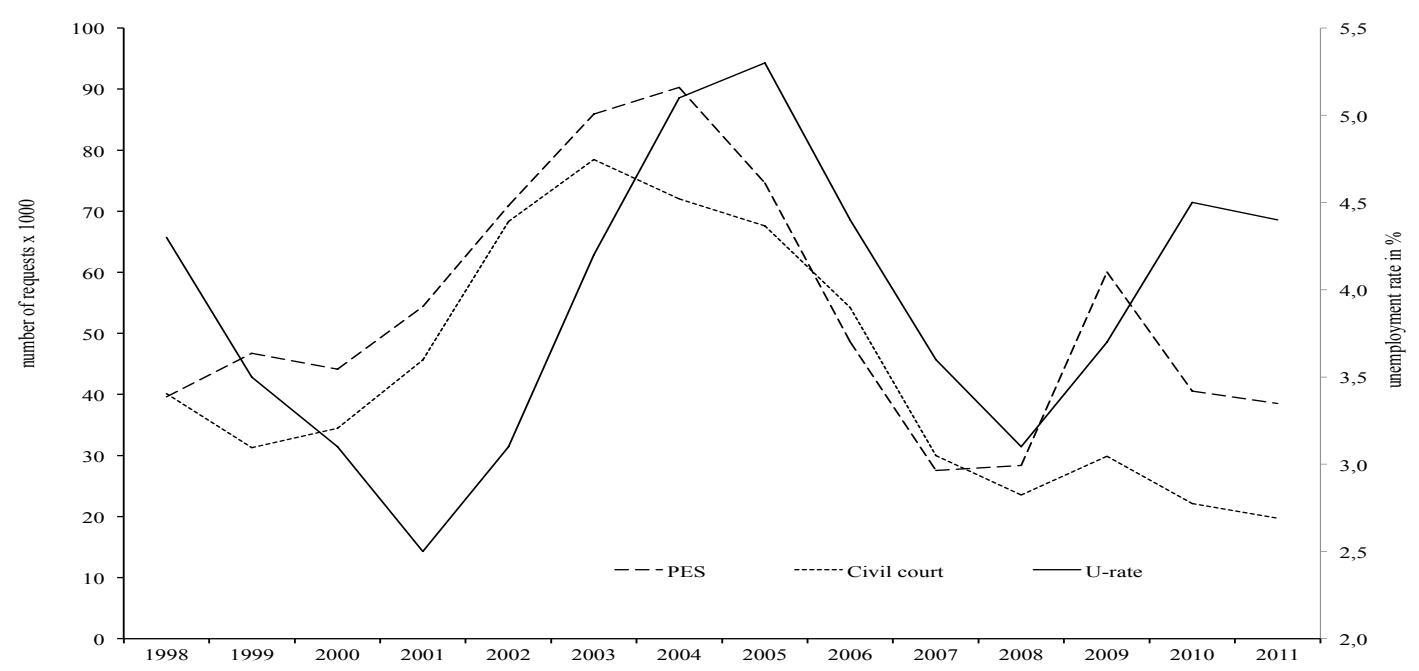

administered by the organization of the courts. Detailed information is stored in paper folders only, each containing a written appeal, a written defense, and the judges verdict. Each folder has a concise description of the reason for dismissal and some employee related characteristics such as job tenure, position, date of birth and earnings. Shortly after a case is closed the folder is moved to and stored in the local courts data archives where it is kept for a period longer than twenty-five years.

Each dismissal case filed at the public employment service is recorded in an Automation of Reports and Consolidated Orders System (ARCOS) database. Other databases that contain information of job dismissals through the public employment service, for example at the Central Bureau of Statistics in the Netherlands, are incomplete (cf. CBS (2011)). The information included in the ARCOS electronic database keeps track of a small number of employer and employee related characteristics, such as the reason for 
dismissal and the duration of the dismissal procedure. Further specific information about each case - including the age, wage, tenure, and the number of working hours per week - is kept in hard-copy files only that are stored in a national archive located in the city of Almere.

The data that have been collected for this study is a representative sample of 2,191 individual dismissal conflicts with full information for the years 2006 to 2009, divided between 1,029 dismissal requests to the civil court and 1,162 dismissal requests to the PES. ${ }^{6}$ The files contain detailed information on the reasons why the dismissal request was imminent. Table 1 summarizes the different dispute origins of the dismissal request processes. The reasons of the disputes are categorized in accordance with the general dispute taxonomy that has been presented in Section 2. Worker dominant reasons include absence from work due to long-term sickness; disciplinary reasons related to conduct, ability or capability, and other substantial reasons. This category corresponds with the area in Figure 1 where $x<0$ and $y>0$. The vast majority of dismissal requests for worker dominant reasons submitted to the PES are cases of long-term illness ( $>2$ years). Firm dominant reasons include redundancy, relocation or reorganization. This category corresponds with the area in Figure 1 where $x>0$ and $y<0$. Both-to-blame reasons contain those cases where it is doubtful which party is responsible most for making the separation compulsory. These include pro forma cases, fairness issues, disagreements and other disturbed relationships between an employee and an employer. This last category corresponds with the area in Figure 1 where $x>0, y>0$ and $x+y<w$ or whenever

\footnotetext{
${ }^{6}$ See Frenk (2013) for detailed information about the data collection and its representativeness for the Netherlands.
} 
$x<0$ and $y<0$.

Table 1 reports the key sorting facts from our empirical exercise. The unconditional distribution shows that approximately $50 \%$ of the cases are firm dominant, $32 \%$ are bothto-blame and the rest (approximately 20\%) are worker dominant. More interesting are the conditional distributions. $69 \%$ of the court cases (32\% of overall observations) belong to the Both-to-blame category. Simultaneously, $72 \%$ of PES cases are Firm dominant. We thus have strong evidence that the Court specializes in the both-to-blam category, while the PES specializes in firm dominant cases.

Table 2 reports differences between the two institutions in the distributions of process duration, tenure, age, gender, hourly earnings and weekly hours worked. All mean differences are significant, except gender. Compared to court, the PES receives dismissal requests for workers who are two years and three months older, have one year more tenure, earn $€ 2.77$ per hour less, and work 1.77 fewer hours per week. In a standard Mincer equation with age and tenure profiles and all other available explanatory variables, but without education, which we do not observe, the hourly wage difference between the court and the PES reduces to about 10 percent. The most substantial difference is found in process durations: PES procedures take a month longer than court rulings. The magnitude of difference is threefold. Table 4 reports the differences in numbers of requests and process duration for different categories of employer size. Three facts can be derived from this table. First, larger firms request dismissal permission more often through court. This finding is in line with the outcomes of related research for small and large firms in other European countries (cf. Bender et al. (2002) for Germany and France; Boeri and 
Jimeno (2005) for Italy). Second, the process duration decreases with firm size in courts and increases with firm size at the PES. Third, the difference in process duration between the court and the PES increases with firm size.

\section{Differences in Procedural Durations}

In Table 3 more detailed information is given on the differences in process duration for the different reasons of requested contract termination. The facts that can be established from Table 3 are as follows. Court and PES procedures for worker dominant reasons take longer. The PES procedure duration outweighs the court procedure duration more than three weeks in all categories. Both-to-blame cases are only sporadically presented to PES. This is due to the fact that the PES is prone to reject dismissal requests that comprise difficult disputes. Not only do duration outcomes differ substantially between the two institutions, but they vary in various other dimensions as well. In order to identify specifically salient process duration differences an econometric model will be estimated.

Let $X, Y$, and $P E S$ be dummy variables, with $X=1$ if $x>0, Y=1$ if $y>0$, and $P E S=0$ representing a court request and $P E S=1$ a request to the PES. This yields the following $[X ; Y ; P E S]$ combinations:

$[0 ; 0 ; 0]$ represents dismissal requests to court of both-to-blame cases (710 observations). $[1 ; 0 ; 0]$ represents dismissal requests to court of firm dominant cases (242 observation). $[0 ; 1 ; 0]$ represents dismissal requests to court of worker dominant cases (77 observations). $[1 ; 0 ; 1]$ represents dismissal requests to PES of firm dominant cases (843 observations). $[0 ; 1 ; 1]$ represents dismissal requests to PES of worker dominant cases (309 observations). 
The combinations $[0 ; 1 ; 1]$ and $[1 ; 1 ; 1]$ are 'good jobs' and not observed in the data; the 10 observations for which $[0 ; 0 ; 1]$ - both-to-blame requests to the PES (see Table 1 ) - are not included in the estimation. This is because the PES considered 8 of the 10 requests as unreasonable, and were denied accordingly. The econometric model specification yields:

$$
\text { Duration }=\beta_{0}+\beta_{1} X+\beta_{2} Y+\beta_{3} P E S+\beta_{12} P E S \times Y+\gamma \boldsymbol{\Gamma}+\varepsilon
$$

Duration is the process length measured in days, $\gamma$ is a vector of parameters, $\boldsymbol{\Gamma}$ is a matrix of explanatory variables. The first column of Table 5 reports parameter estimates of the baseline model, when $\boldsymbol{\gamma}=\mathbf{0}$. The model's parameters have straightforward interpretations: $\hat{\beta}_{0}=9.04$ is the average length of court procedures for both-to-blame cases. $\hat{\beta}_{1}=1.35$ is the - insignificant - difference in court duration between firm dominant and both-to-blame cases. $\hat{\beta}_{2}=24.2$ is the difference in court procedural length between worker dominant and both-to-blame cases. $\hat{\beta}_{3}=26.1$ is the difference in procedural length between PES and court procedures for firm dominant and both-to-blame cases. $\hat{\beta}_{12}=1.50$ is the - insignificant - difference-in-difference estimate in procedural durations between the PES and the court and between worker and firm dominant cases. These baseline estimates confirm the results from Table 3 that when it is both-to-blame which party is resposible most for the requested termination of the job contract, i.e. when $x<0$ or when $y<0$, the PES job ending procedures are much longer than the court procedures.

The second column in Table 5 reports parameter estimates when the model is extended with a set of -22 - additional explanatory variables. The $F$-test yiels $F(22,2154)=1.92$ 
with $p=.006$. The marginal effects on process duration of Hours - one contracted hour more per week - and Wage - one Euro more in the hourly wage - are practically similar and equal to one additional procedural hour. ${ }^{7}$

\section{Differences in Procedural Outcomes}

Not all requests submitted by employers are granted. The court denies 7.5 per cent of all dismissal requests, the PES denies 12.4 per cent. Table 7 shows duration differences of granted and denied requests broken down by the three reasons for submission. The following facts can be derived from Table 7. Denials in court take more time than decisions to grant a request. Denials at the PES take less time (except the 10 exceptions of the both-to-blame cases). The largest differences are observed in court for the firm dominant cases and for the both-to-blame cases.

\section{Estimating Differences in Firing Costs}

Differences in firing costs are computed for granted dismissal requests of individual workers obtained from the public employment service or from the civil court. ${ }^{8}$

Before starting a civil court procedure the employer is obliged to pay a court fee. The size of this fee depends on the legal form of the employer. The employer will also incur the costs of ongoing wage payments for the duration of the dismissal. This duration period can be divided into two components. The first component is the duration of the civil court procedure; or the time the court needs for a verdict. This starts at the moment a

\footnotetext{
${ }^{7} \mathrm{~A} 40$ hours working week lasts 7 days. The marginal effects of procedural length per hour are $40 / 7 \times .178=1.02$ and $40 / 7 \times .172=.98$, respectively .

${ }^{8}$ See Pfann (2006) for how to measure heterogeneous firing costs in Dutch firms.
} 
request is registered and lasts until the moment the court reaches a decision. The second component is the time between the verdict and the duration of employment contract termination, which is determined by court ruling. The civil court is not bound to observe the statutory notice period; and can decide when the employment contracted shall be dissolved. The final cost component is the firing costs to be borne by the firm.

Civil courts "are free to assess the amount of compensation to be paid by the employer; there is no statutory minimum or maximum. This makes it very difficult to forecast the results of the procedure." (op cit. Jacobs (2004), p103). However, Dutch civil courts do have a guideline to determine these costs; a formula for cantonal judges states that firing costs should, in principal, be equal to the product of three factors. Factor A is a weighting factor of the years of age of the employee $A=0.5$ for age $<35 ; A=1$ for $35 \leq$ age $<45 ; A=1.5$ for $45 \leq$ age $<55$, and $A=2$ for age $\geq 55$. Factor $\mathrm{B}$ is the gross monthly wage. Factor $\mathrm{C}$ is a correction factor that is determined by the civil court, with $0 \leq C \leq 2$. If $C<1$, the employee is held liable for negligence, and if $C>1$ the employer is held liable. In all other, mostly pro forma, cases $C=1$. The compensation formula provides guidance, but the courts are free to determine the exact amounts indeed. The data on compensation decisions are obtained directly from the court records.

An employer that submits a request for dismissal to the public employment service will incur ongoing wage costs during the time of the dismissal procedure. The period can be divided into three parts: the procedural time, the time to notice, and the period of notice. The procedural time is the time between submission and the pronouncement. The time to notice is the period between the pronouncement and the start of the notice 
period. The notice period is defined by the employees years of tenure. Currently, a notice period equals 1 month for tenure less than 5 years, 2 months for tenure less than 10 years, 3 months for tenure less than 15 years, and 4 months for tenure of 15 years or longer.

Table 8 shows the outcomes of the computations of idiosyncratic firing costs based on our data set on individual dismissal cases. The average firing costs that a firm faces if a dismissal request is approved by the PES is 7,480 . That is about 500 times the average hourly wage rate of a worker permitted to be laid off by the PES. The average firing costs a firm faces if a dismissal request is submitted to and approved by the civil court is 30,982. That is about 2,000 times the average hourly wage rate of a worker permitted to be laid off by the court. The average firing costs for the civil court procedure are found to be four times the average PES firing costs. The median costs are two times larger.

Another striking dissimilarity between the two procedures is the differences in variances of the firing costs. The standard deviation of the firing costs through the civil court is $€ 54,808$; the standard deviation of firing costs associated with the public employment service is $€ 5,648$, almost ten times higher. Dismissal procedures through court are characterized by higher costs and much larger variations in costs and duration. Given these outcomes, why then do not all employers apply for dismissal permission from the public employment service always? The answer is primarily an argument of expected time-saving. The decisions taken by the PES can be challenged in court by the employer as well as by the employee; and cases of troubled employer-employee relationships will not be dealt with by the public employment service. If a request is considered by the PES to be unreasonable, permission to terminate the employment contract shall not be 
granted (but valuable time and costs shall be foregone). The key empirical facts can be summarized as follows:

- In aggregate data, the share of requests at the PES increases in recessions.

- PES authorization takes longer than the court ruling. The difference in procedural duration - of almost a month - is the largest difference between the two institutions.

- PES specializes in firm dominant cases.

- Courts specialize in both-to-blame cases.

- Worker dominant cases are equally split between the two institutions.

- Court procedures are more expensive with larger variations in costs and duration.

- Large firms use the court more intensively.

\section{A Search Model with Endogenous Sorting}

\subsection{The Dual Dimension of Job Level Productivity}

There is a measure 1 of identical risk neutral workers that are matched to a firm in an imperfect labor market. There is no aggregate uncertainty and we focus on stationary equilibria. Jobs are created by the meeting of unemployed workers and vacancy in a imperfect labor market. The matching function is $x(u, v)$ with constant return to scale, and we shall indicate with $\theta$ the vacancy unemployment ratio. The job filling rate for a firm is $q \theta)$ and the job finding rate for the worker is $\theta q(\theta)$. Firm post vacancies at a flow cost of $c$, but we postpone the job creation decision to the general equilibrium dimension.

Firms and workers discount the future at a rate of preference $r$ and jobs die exogenously at rate $\delta$. Workers survive the firm specific job $\delta$ and survive into unemployment. 
The joint output of a single job is characterized by two key idiosyncratic dimensions. The component are match specific. The $y$ component refers to the technological productivity of the firm. The $x$ component refers to the individual characteristics of the job. We can think of $x$ as being drawn from a continuous random variable $X$ of worker specific characteristics such as worker attitude toward the job, health, motivation, etc. Conversely, $y$ is drawn from a random variable $Y$ that refers to technological conditions, market characteristics, demand conditions that have nothing to do with the worker. The two dimensions are drawn from a joint continuous distribution $f(x, y)$ so that in the most general form we have that

$$
F(x \leq a, y \leq b)=\int_{-\infty}^{b} \int_{-\infty}^{a} f(x, y) d x d y
$$

where $F$ is the joint cumulative distribution. We say that a job space is complete when $\mathrm{x}$ and y are continuous with support $X \in \Re$ and $Y \in \Re$. In a complete job space there is a job in any set $A \in \Re^{2}$. To simplify the general equilibrium of the model, we assume that the individual productivity $X$ is independently distributed from the technological productivity $Y .{ }^{9}$ The total idiosyncratic productivity of a single job is the sum of the two components and for simplicity we shall indicate with $z=x+y$ the total idiosyncratic productivity of the job and with $F_{X+Y}$ the joint cumulative distribution. ${ }^{10}$

\footnotetext{
${ }^{9}$ The job destruction and the existence of the two types of institutions in equilibrium does not depend on the assumption of independence that can easily be dropped

${ }^{10} \mathrm{~A}$ basic result in probability theory (Ross, 2002) is that $F_{X+Y}$ is the convolution of the distributions $F_{X}$ and $F_{Y}$ and the denstity $z$ is

$$
f_{X+Y}(z)=\int_{-\infty}^{\infty} f_{X}(z-y) f_{Y}(y) d y
$$
}


To make the derivation simple, we also assume that the distribution $F_{X+Y}$ has finite support over the interval $\left[z^{l}, z^{u}\right]$

\subsection{The Life of a Job, Ages and the Key Value Function}

We assume that each newly created job has a fixed initial productivity $\bar{z}=\bar{x}+\bar{y}$. The idea is that a job has an initial learning phase in which the true productivity is not totally determined to the parties. The average duration of the learning phase is $\frac{1}{\lambda}$, so that at the end of this period the firm learns the long term quality of the job.

Conditionally upon on the realization of the shock $\lambda$, the firm (or the match at this stage) learns its long term productivity value $z$. For simplicity, we assume that the productivity is fixed thereafter and no other productivity shocks hit the firm. Nevertheless, conditional upon the realization of the shock, the firm faces a key continuation decision. The firm may or may not endogenously destroy the job. If the job is continued, it enters its maturity stage. We say that a mature job is a good job with idiosyncratic productivity $x+y$. If the firm wants to interrupt the job it will enter into a firing procedure.

There are two possible ways to terminate a job: either through a permission via Public Employment Service or through a court ruling. We' discuss in the next stage the two different procedures. In what follows we shall indicate with $J$ the value of a new job and with $J^{g}(x+y), J^{\text {pes }}(x+y)$ and $J^{c t}(x+y)$ the value of a good job, a job that is under a $P E S$ procedure and a job that is under a court procedure 
$(r+\delta+\lambda) J=\bar{x}+\bar{y}-w(\bar{x}+\bar{y})+\lambda \int_{y} \int_{x} \operatorname{Max}\left[J^{g}(\xi, \nu), J^{p e s}(\xi, \nu), J^{c t}(\xi, \nu)\right] d F(\xi, \nu) d \xi d \nu$

Equation (5) is the general expression for the value of a new job. The firm effectively discount its flows at rate $r+\delta+\lambda$. Further, the flow value of a new job is $\bar{x}+\bar{y}-w(\bar{x}+\bar{y})$. Conditional on the realization of the $\lambda$ shock, the firm learns its long run productivity and endogenously choose i) whether the job should continue and ii) whether the separation procedure should follow the court ruling or the public employment service.

The wage is endogenously determined. We will assume that the firm and the worker split the surplus in a Nash Bargaining fashion whenever the surplus is positive. Conversely, when the job is undergoing a dismissal procedure and the job has no surplus, the worker partecipation constraints (in the forms of its life time value of unemployment value binds. The partcipation constraint is given by the endogenously determined unemployed permanent income, which we shall indicate with $r U$. If the surplus for the job is $S(x+y)$, the wage rule reads

$$
w(x+y)= \begin{cases}\operatorname{argmax}\left\{(W-U)^{\beta}(J-V)^{1-\beta}\right\} & \text { if } S(x+y) \geq 0 \\ r U & \text { if } S(x+y)<0\end{cases}
$$

where $S(x+y)=J(x+y)+W(x+y)-V-U$ is the surplus from the job. The same wage rule was used by Acemoglu (1998) in a model of bad jobs. 


\subsection{The Dismissal Procedure}

\section{Fully Operational Jobs}

A good job is fully operational and delivers positive value to the firm $\left(J^{g}(x+y)>0\right.$ at the realized productivity $x+y$. A good job survived the learning phase and stays operational until the firm dies for exogenous reasons at rate $\delta$. It thus follows that

$$
J^{g}(x+y)=\frac{x+y-w(x+y)}{r+\delta} ; \quad J() \geq 0
$$

The derivation of the wage is standard in search models and is coherent with Pissarides (2000). Indicating with $b$ the flow value of unemployment, the wage in a good job reads

$$
w(x+y)=b(1-\beta)+\beta(x+y+c \theta)
$$

where the wage is the linea combination of the value of unemployment and the productivity of the job, augment by the rent flow $c \theta$. Substituting the wage into equation 7 , the value $J^{g}(x+y)$ is clearly increasing in both characteristics of productivity $x$ and $y$. In what follows we will make use of the concept of the job contour, excatly as we did in section 2. Using the wage rule, the value of the job can be written as

$$
J^{g}(x+y)=\frac{(1-\beta)(x+y-r U)}{r+\delta}
$$


where $r U=b+\frac{c x}{1-\beta} \theta$ (see appendix for derivation). The previous expression is the value of the job contour, very similar to the concept used in section 2. For given value of unemploymetn $U$, the job contour is the combination of $x$ and $y$ that guarantee to the firm a value of $\bar{J}$. Note that the contour in the space $x, y$ have the same properties of section $2^{11}$ The marginal good job delivers zero value to the firm and its contour $J(\tilde{x}+\tilde{y})=0$ reads

$$
\tilde{y}=-\tilde{x}+r U
$$

The intuition is very clear. Since the productivity will permanently be at the value $x+y$ the firm will hold a good job until the flow profit from the marginal job is positive. Any job above in the $(x, y)$ space above marginal $\tilde{y}, \tilde{x}$ contour is fully operational. Figure 1 illustrates this point.

\section{Public Employment Service}

When a job has negative value, the firm enters the firing procedure. To begin with, we assume that the firm has the option of applying for a firing position through the Public Employment Service. For simplicity, we assume that the application has no cost. Conditional on the application, the firm is entitled to firing at the instantaneous rate $s=s(x)$. The idea of stochastic firing was introduced by Garibaldi (1998). The firm takes as given the arrival rate of stochastic firing permission. The higher is $s$, the quicker is the firing authorization. Clearly, as $s \rightarrow \infty$, firing takes place immediately and the

\footnotetext{
${ }^{11}$ The job contours i) are downward sloping linear function, ii) have a unit slope in absolute terms and iii) delive higher values to the north east.
} 
firm immediately fires the worker. Conditional upon a firing permission, the firm may be forced to a firing cost. For simplicity, we assume that in the case of PES procedure, the firing cost is zero. This implies that the cost of firing in the case of PES is just a time cost, due to the fact that the job must be in place as long as the firing permission arrives. This is also coherent with the evidence provided in section 3.

In a general framework one can assume that PES behavior may be affected by the worker or firm characteristic, so that $s=s(x, y)$. The idea is that a job with a very poor worker characteristics may increases or decrease the chance of a firing permission, so that PES changes procedure depending upon the specific type of dismissal it faces. In other words we will say that the PES behavior is biased toward worker characteristics when $s^{\prime}(x)<0$. Conversely, PES behavior is neutral when $s(x)=s^{\text {pes }} \forall x$. In what follows we will consider the case of a PES neutral and will postpone the discussion of a PES biased in the extensions.

The value of a job at the PES reads

$$
(r+\delta) J^{p e s}(x+y)=x+y-w^{p e s}(x+y)+s^{\text {pes }}\left[\operatorname{Max}\left(0, J^{p e s}(x+y)\right)\right]
$$

Since positive valued jobs are operational, in equation (9), the PES procedure yields negative total value to the firm and $J^{P E S}>0$, so that we can get rid of the max operator. In addition, the wage is determined by the worker's participation constraint so 
Figure 3: The Job Space and the Marginal Job Contour

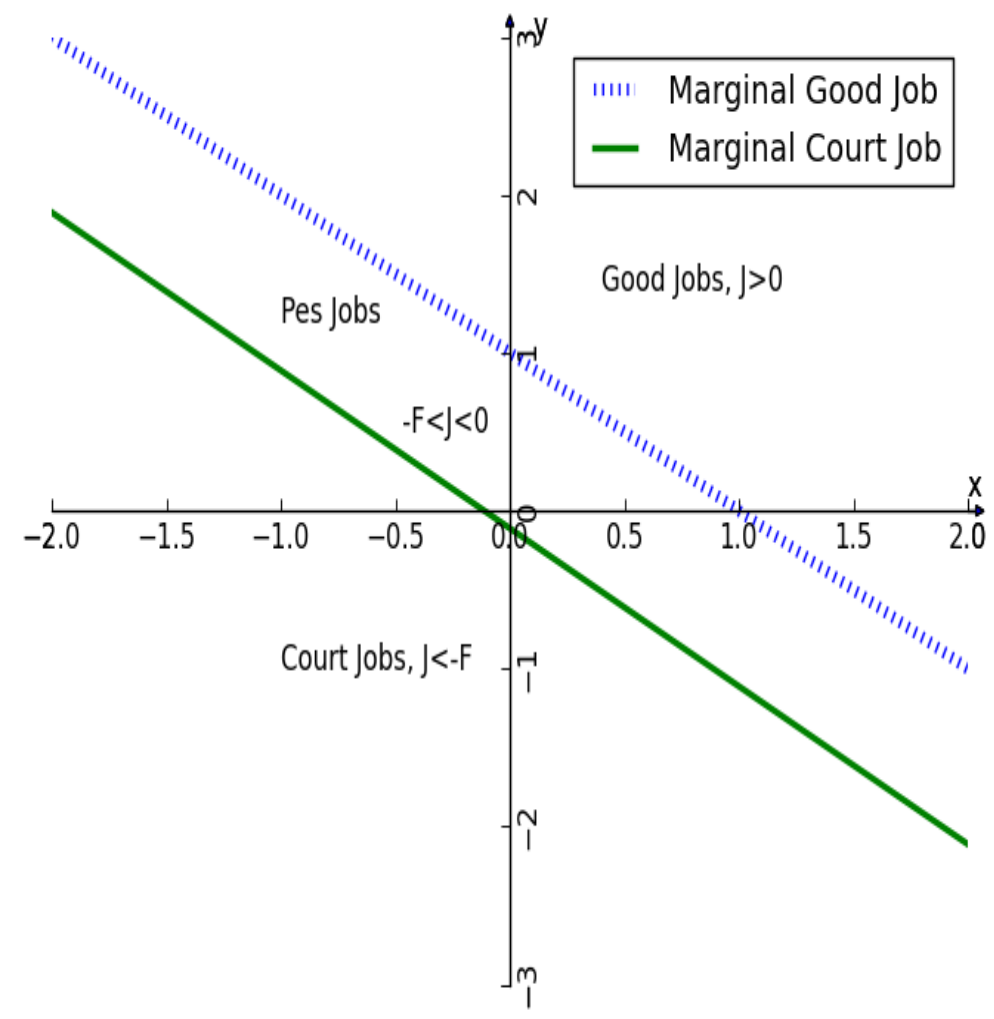


that $w^{\text {pes }}=r U$. In other words, the value of a job undergoing a PES procedure is

$$
J^{\text {pes }}(x+y)=\frac{x+y-r U}{r+\delta+s^{\text {pes }}} ; \quad J^{\text {pes }}(x+y) \leq 0
$$

An important caveat is in order. In our model of time to fire, as in most models of costly dismissal, parties would have incentives to bargain over the dismissal costs to avoid deadweight losses linked to employment protection legislation. In the present setting, workers receive their outside option while firms incur job losses. This is fully coherent with the Dutch model, where firms need prior authorization for dismissing workers. Yet, parties would still have incentives to bargain over the deadweight losses and to avoid the dismissal procedure. In models of perfect information, such potential deals are ruled out by assumption, in line with the mainstream employment protection legislation literature (Bentolila Bertola, 1990). Our assumption is also coherent with the data, since 80 percent of job termination authorized by the Court are pro forma cases. In models of imperfect information, bargaining over the deadweight losses would imply the use of court ruling in equilibrium. Models of strikes are coherent with these setting (Kennan, 1986, and Kennan and Wilson, 1993). More recent theories on bargaining with deadlines would also imply the use of court ruling in equilibrium.

\section{Court Ruling}

Firms also have the option of going to court. The court procedure has two key feature. It involves a court firing permission $s^{c t}$ that is strictly quicker than a PES procedure. In 
other words, $s^{c t}>s^{\text {pes }} \forall x, y$. Conditional on a firing permission, the firm incurs a strictly positive random firing tax. Firing costs are drawn from a distribution $G \sim\left(-F, \sigma_{F}^{2}\right)$. Note that the in the Dutch model the court ruling is mainly in terms of a wage transfer to a worker, while in the paper we emphasize the firing costs. In search economies with flexible wages and Nash bargaining, mandatory transfers are prepaid by the workers in forms of lower entry wages (Garibaldi and Violante, 2005).

Since the firm is risk neutral, the expected value of a job undergoing a court procedure reads

$$
(r+\delta) J^{c t}(x+y)=x+y-w^{c t}(x+y)+s^{c t}\left[\operatorname{Max}\left(-F, J^{c t}(x+y)\right)\right]
$$

Confronting equation (9) and (10) it is clear that the court offers to the firm an option to stop losses. When the expected value of a job is sufficiently bad, it must be optimal entering the expensive firing procedure. We can thus also get rid of the max operator also in equation (10) and define the job in court as

$$
J^{c t}(x+y)=\frac{x+y-r U-s^{c t} F}{r+\delta+s^{c t}} ; \quad J^{c t}(x+y) \leq-F
$$

where the worker's participation binds and $w^{c t}(x+y)=r U$ This suggests that there exists a job contour such that

$$
J^{c t}\left(x^{c t}+y^{c t}\right)=J^{p e s}\left(x^{c t}+y^{c t}\right)
$$

Simple algebra shows that in the case of a neutrally biased PES, the marginal court job 
thus solves

$$
y^{c t}=-x^{c t}-r U-\frac{s^{c t} F\left(r+\delta+s^{p e s}\right)}{s^{c t}-s^{p e s}}
$$

We have thus established some important results.

Proposition 1 The job space is complete and in equilibrium good jobs, PES jobs and court jobs will simultaneously coexist.

Proof. The proof is straightforward. Just notice that the contour of the marginal PES job lies strictly below the marginal good job as long as $\frac{F\left(r+\delta+s^{p e s}\right)}{s^{c t}-s^{p e s}}>0$, which is guaranteed from the fact that court ruling is quicker than PES procedure, or that $s^{c t}>s^{\text {pes }}$.

The economics of Proposition (1) is the following. In choosing between the court and the PES procedure, the firm has to trade off between a higher expected firing cost and quicker court ruling procedure. If the job characteristics are not too bad, the firm strictly prefers a longer queue through the PES offices. Nevertheless, as any of the job characteristics turn out sufficiently bad in any of the characteristics, the firm is willing to exercise the stop loss option guaranteed by the expensive court procedure.

Proposition 2 Uncertain dismissal cases $(x<0, y<0)$ go to court.

Proof. The proposition is true in partial equilibrium as long as $r U>\frac{\left(r+\delta+s^{p e s}\right) s^{c t} F}{s^{c t}-s^{p e s}}$. Yet in general equilibrium $U$ is an endogenous variable and the parameter restriction is complicated. In any event, the tendency of uncertain cases to go to court is also evident from Figure 3. Since the court offers an option to stop losses, the model certainly predicts that sufficiently difficult cases go to court. 
Result 4.1 Firms are more likely to enter the PES procedure when court firing costs increase, when the PES permission frequency increases, and when court ruling becomes slower.

Proof. The proof is based on a simple comparative static over the marginal job contour of equation (12). The marginal contour shifts down with an increase in firing costs $F$, a fall in court speed $s^{c t}$ and an increase in $s^{\text {pes }}$.

\subsection{Job Creation and General Equilbrium}

Using the marginal contour in good job and in court described by equations (8) and (12), and recalling the definition of $z=x+y$, the expected value of a job at PES and in court read respectively

$$
\begin{gathered}
\left.S^{p e s}\left(\theta, z^{c t}, \tilde{z}\right)=-\frac{1}{r+\delta+\lambda+s^{p e s}} \int_{z^{c t}(\theta)}^{\tilde{z}(\theta)} F_{X+Y}(m)\right) d m \\
\left.S^{c t}\left(\theta, z^{c t}\right)=-\frac{1}{r+\delta+\lambda+s^{c t}} \int_{z^{l}(\theta)}^{z^{p e s}(\theta)} F_{X+Y}(m)\right) d m
\end{gathered}
$$

These two expected values describe two important features of the model. First, the expected costs of the procedures are endogenously determined. Second, the costs tends to zero as the arrival rate of the procedure becomes infinitely large. In other words, the costs of the time consuming firing depends crucially on the speed of the procedures. Note also that these two costs are dissipated and can not be undone y wage transfers. In other words, they act as a firing tax. We are now in a position to define the general equilibrium. 
The value of new jobs, after a few steps of algebra is

$$
(r+\lambda+\delta) J=\bar{x}+\bar{y}-w(\bar{x}+\bar{y})+\lambda(1-\beta) \int_{z^{g}}^{z^{u}}\left(1-F_{X+Y}(m)\right) d m-\lambda S^{c t}\left(\theta, z^{c t}\right)-\lambda S^{p e s}\left(\theta, z^{c t}, \tilde{z}\right)
$$

The previous expression makes clear that the firm anticipates the cost of the procedure and depressed the value of a new job. The wage in the new job is

$$
w(\bar{x}+\bar{y})=b(1-\beta)+\beta\left[\bar{x}+\bar{y}+c \theta+\lambda S^{c t}\left(\theta, z^{c t}\right)+\lambda S^{p e s}\left(\theta, z^{c t}, \tilde{z}\right)\right]
$$

The previous equation highlights an important result in the economics of employment protection legislation. The complex procedure imposes a costs to the firm that is evident during the procedure, but in addition improves the worker bargaining power at the time of job creation, thus inducing a sort of wage pressure. Garibaldi and Violante (2005) have similar results for firing taxes. Using the wage equation (14), the free entry condition imposes that the value of a vacancy be zero $(V=0)$, so that the value of a new job is equal to expected

$$
\frac{c}{q(\theta)}=J\left(\theta, z^{p e s}, z^{c t}\right)
$$

Definition 5 The general equilibrium is a set of employers value functions $\left(J^{i}, W^{i}\right)$, value of unemployment $r U$, marginal contour $\left(z^{c t}, z^{g}\right)$ market tightness $(\theta)$, wages $w^{i}$, aggregate stocks $\left(n^{i}, u\right)$ for good jobs, PES jobs and court jobs ( $i=g$, ct, pes) such that

1. wages $w^{i}$ satisfy the wage rule; equation (6); 
2. $\left(z^{c t}, z^{g}\right)$ satisfy the marginal contours; equations (8) and (12);

3. market tightness $\theta$ satisfy the job creation condition; equation (15)

4. aggregate stocks satisfy the balance flow conditions (see Appendix).

We are now in a position to establish existence and few basic comparative static results.

Result 4.2 Equilibrium exists and it is unique.

Proof. See appendix.

Result 4.3 An increase in the arrival rate of firing authorization at both institutions $\left(s^{\text {pes }}, s^{c t}\right)$ increase market tightness and has ambiguous effect on unemployment.

Proof. This results is derived from equation (15). The increase in the arrival rates increases the value $J$ at given market tightness. General equilibrium is restored by an increase in expected search cost linked to the the entry of new vacancy in to the market that drive up $\theta$.

As a corollary to the last result, one may want to consider a particular case of the model, namely one in which the PES does not operate. The model with only a court ruling is just a limit case of the model we just solved in which $s^{\text {pes }} \rightarrow 0$. If PES authorization is never warranted, the option to avoid the court has no value in equilibrium and firms are obliged to use the court. Such economy features larger expected firing costs, with standard predictions that follow from the literature and are summarized in the following corollary. 
Corollary 4.1 In an economy with no PES expected firing costs are higher. Job destruction is lower and so is job creation, with ambiguous effects on unemployment.

The result of the corollary naturally poses the question on the political economy dimension of an institution like the PES, as well as on the longevity of the Dutch model and its political resilience.

\subsection{The Longevity and Resilience of PES}

The model provided the economics of the trade off between the court and the PES procedure and rationalizes the sorting of different jobs across the two institutions. As in most search models with risk neutral individuals, the existence of the two institutions is taken as given. Yet, in the spirit of the original contribution of Saint-Paul (1993), the model can be used to understand the longevity and resilience of institutions in terms of political economy. This section follows this approach and considers the welfare implications of removing the PES, the institution that was established in the Netherlands in the middle of the German occupations, an admittedly crisis situation. Yet, the institution proved to be remarkably resilient to the subsequent seventy years of recurring fierce political debates. $^{12}$

Consider the equilibrium value functions of different individuals. The value functions

\footnotetext{
${ }^{12}$ As of January $1^{\text {st }}, 2015$ a change in the Dutch dismissal law is effective, putting a $€ 75,000$ cap on the maximum severance payment a court can adjudge. The preventive a priori dismissal tests performed either by the civil court or by the public employment service remain in place. The employer's choice which of the two established organizations to ask for permission to terminate a permanent worker's contract continues to be based on the grounds for dismissal.
} 
of unemployed workers, as well as individuals under a firing procedure read

$$
r U=b+\frac{\beta c}{1-\beta} \theta
$$

Workers employed in good job enjoy the following utility

$$
W^{g}(x+y)=\frac{b(1-\beta)+\beta(x+y+c \theta)+\delta U}{(r+\delta+\lambda)}
$$

The welfare of workers in newly employed jobs is more at $\bar{x}+\bar{y}$ is more complicated, but can be compactly written as follows.

$$
W(\bar{x}+\bar{y})=\frac{w(\bar{x}+\bar{y})+\lambda \frac{(1-\beta)}{\beta} \int_{r U}^{z^{u}}\left(1-F_{X+Y}(m)\right) d m+\delta U F_{X+Y}(r U)}{(r+\delta+\lambda)}
$$

where the wage $w(\bar{x}+\bar{y})$ is given by equation (14). The three values functions allow us to derive a simple welfare results.

Result 4.4 The value functions of the unemployed $(r U)$ and on workers employed in good jobs $\left(r W^{g}\right)$ is strictly increasing in the arrival rate of firing permissions at both institutions ( $s^{\text {pes }}$ and $\left.s^{c t}\right)$. Conversely, the speed of firing permission has ambiguous effects on the value function of newly appointed workers $(W(\bar{x}+\bar{y}))$

Proof The proof depends directly from Result 4.2. Since $\frac{\partial \theta}{\partial s^{i}}>0$, it is sufficient to notice that from the value functions we have that $\frac{\partial r U}{\partial \theta}>0, \frac{\partial W^{g}}{\partial \theta}>0$ while it is not possible to unambiguously sign $\frac{\partial W(\bar{x}+\bar{z})}{\partial \theta}$. 
The economics of the previous result is fairly simple. First, recall that an increase in the arrival rate $s^{i}$ is akin to a reduction in firing costs. Unemployed workers favour such reductions since their utility is increasing in the job finding rate. The change in $s^{i}$ has similar results on workers employed in good jobs, since such workers have already learned their job specific match $z$ and will benefit of a higher job finding rate if their job had to be dissolved. The uncertainty of the policy rests with the newly appointed workers, that face a shorter duration of their employment in the aftermath of the increase in $s$.

Result 4.5 If the median voter is employed in a good job, the elimination of the PES is vetoed by the majority of workers and the PES is resilient.

Proof. If $s^{\text {pes }} \rightarrow 0$ equilibrium expected firing costs are higher and the value function $W^{g}$ will be lower since market tightness will be lower.

It is thus in the interest of most agents to keep the PES alive, although during recessions when unemployment rises and more dismissal requests are received by the PES, its political basis is frailer. Hence the recurring political attacks. As we argued in the previous section, the elimination of the PES can be represented by an economy in which there is only a court ruling. In such an economy expected firing costs will be higher. With higher firing costs the job finding rate falls and both unemployed as well as workers employed in good jobs are worse off, in the sense that they would enjoy a lower lifetime utility. In other words, Result 4.5 ensures that a coalition formed by workers in good jobs, unemployed workers as well as workers undergoing a firing procedure will form a 
majority and will block the removal of the PES. ${ }^{13}$

\section{Extension and Discussions}

\subsection{Institutional Bias}

Institutional bias is defined as "a tendency for the procedures and practices of particular institutions to operate in ways which result in certain social groups being advantaged or favoured and others being disadvantaged or devalued." 14.

In the baseline model we assumed that the behavior of the institutions were neutral with respect to the type of dismissal faced. While we do not have in mind any clear directions of particular biases, our model is flexible enough to consider the possibility that the PES or the court behave differently for different dismissal cases. In this section we present a simple extension, based on the assumption that the PES is biased towards certain worker characteristics. Of course, a similar specification holds for court biases.

\section{The Model with Institutional Bias}

Formally, it holds that the PES is biased whenever $\frac{\partial s}{\partial x} \neq 0 \neq \frac{\partial s}{\partial y}$, so that the the arrival rate depends on the job characteristics faced. In this section we explore the implications of the following bias

\footnotetext{
${ }^{13}$ In the model, workers undergoing a firing procedure enjoy the same lifetime utility of the unemployed $r U$.

${ }^{14}$ Followed by: "This need not be the result of any conscious prejudice or discrimination but rather of the majority simply following existing rules or norms." Oxford Reference: http://www.oxfordreference.com/
} 


$$
s^{p e s}(x)= \begin{cases}\bar{s} & \text { if } x<0 \\ \underline{s} & \text { if } x \geq 0\end{cases}
$$

with $\bar{s}>\underline{s}$. Equation 19 suggests that PES procedure takes longer when the dismissal is worker dominant. We can thus call such a function a representation of Pro Worker bias by the PES.

The solution of the model, with the particular bias assumed in equation (19), is not too different from the baseline model. The job contour is identical to that of equation (8). The marginal contour for the court job reads

$$
y^{c t}=-x^{c t}-r U-\frac{s^{c t} F\left(r+\delta+s^{p e s}\left(x^{c t}\right)\right)}{s^{c t}-s^{p e s}\left(x^{c t}\right)}
$$

Using the specification of the bias of equation (19), the marginal contour is described by Figure 4. The contour is step-wise downward sloping functions with positive intercept in the second quadrant and negative intercept in the fourth quadrant. The job creation condition is similar to the baseline case and it is reported in the appendix. The main results of the extension are the following

Result 5.1 When the PES is biased in a Pro Worker form, or along the rule specified in equation (19) the following is true: i) the job space is complete, ii) PES specializes in firm dominant dismissal cases and iii) all uncertain cases go to court.

The previous result and the specification of equation 19 suggest a simple empirical implication, namely that the duration of the PES procedure takes longer when the cases 
Figure 4: The Job Space with Institutional Biases

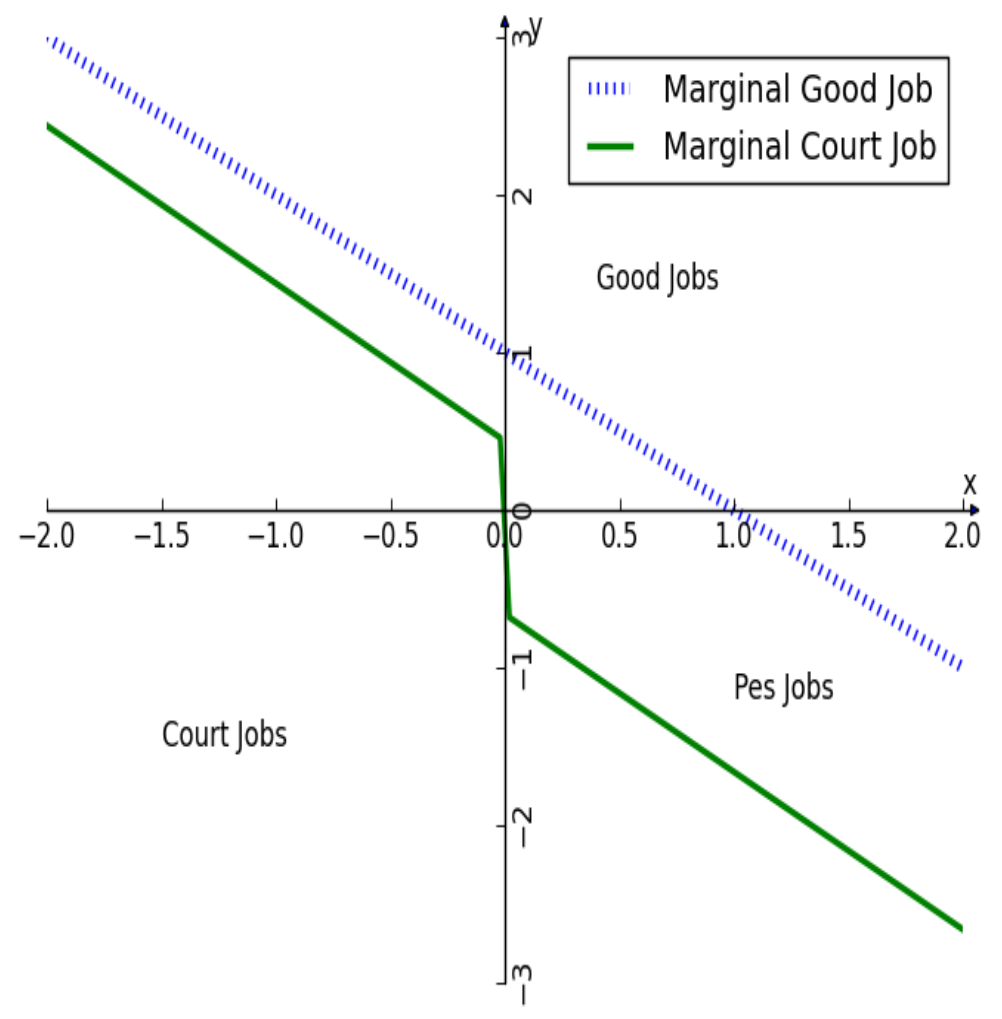

are worker dominant. Such implication can be easily taken to the data, as we do in the following subsection. Obviously, a similar argument to that described in equation (19) can be applied to the behaviour of the court. We do not formalize such a bias in this section, but we do assess its empirical evidence.

\section{Estimating Institutional Bias}

Institutional bias is thus linked to specific characteristics of a worker or groups of workers. If the PES and the court would use different decision rules, the first obvious way to test that is to analyze possible differences in procedural duration with the PES as a modifying 
variable. Equation (4) is then adjusted as follows

$$
\text { Duration }=\beta_{0}+\beta_{1} X+\beta_{2} Y+\beta_{3} P E S+\beta_{12} P E S \times Y+\boldsymbol{\gamma} \boldsymbol{\Gamma}+\boldsymbol{\gamma}^{\boldsymbol{w}}\left(P E S \times \boldsymbol{\Gamma}^{\boldsymbol{w}}\right)+\varepsilon
$$

where $\boldsymbol{\gamma}^{\boldsymbol{w}}$ denotes the vector of bias parameters associated with worker characteristics $\boldsymbol{\Gamma}^{\boldsymbol{w}}$.

Table 6 reports parameter estimates when interaction terms are included to investigate the influence of worker and job characteristics on procedural differences between the two institutions. The $F$-test of added variables is $F(5,2149)=8.51$ with $p=.000$. The results are remarkable. They show a clear difference between the PES and the court in various dimensions. The average PES procedure takes 9.7 days longer for women than for men. The marginal effect of one hour per week more work extends the PES procedural duration with 3.7 days (See footnote 6). Earning one Euro per hour more lengthens the PES procedure with 4.6 days. Variations in court duration are insignificant along all these three dimensions. How to interpret these results? One way to think about this is that the PES shows Pro Worker Bias in case of longer durations of job exit arrival times. Then the institutional bias is such that the PES favors female workers, full-time positions, and high wages. In our model, the match reacts to such biases by sorting firm dominant cases into PES. 


\subsection{Aggregate Productivity and Firing Procedure}

Figure 2 clearly shows that when unemployment is rising, the request at the PES increase relatively to the request at the court. It is thus natural to use our model to study the impact of aggregate conditions on the proportion of PES application. The basic idea is that, following the lines of Mortensen and Pissarides (1994), the productivity of a single job is now $p+x+y$ where $p$ is an aggregate component. The model is identical to the baseline model with the only difference being the parameter $p$ that is added to the contour.

We analyse the effects of aggregate productivity in two steps. First, study whether the link between the increase of request a at the PES during adverse aggregate condition is a simple consequence of the

\section{Statistical Illusion}

The aggregate productivity $p$ has impact on the marginal job contours $(\tilde{x}, \tilde{y})$ and $\left(x^{c t}, y^{c t}\right)$. In terms of Figure 3, an increase in $p$ shifts up both contours and fewer jobs enter the firing procedure. This is hardly surprising and it represents a basic result in any reasonable model of job creation and destruction. The more interesting question is what happens to the proportion of jobs that use the PES procedure.

The proportion of job destruction requests to the PES relative to all dismissal request $\rho^{\text {pes }}(p)$ is defined as

$$
\rho^{\text {pes }}(p)=\frac{F_{X+Y}(\tilde{z})-F_{X+Y}\left(z^{c t}\right)}{F_{X+Y}(\tilde{z})}
$$


Aggregate conditions affect the marginal contour as well as the proportion $\rho^{\text {pes }}(p)$. The actual impact will depend on the distribution $F_{X+Y}$. We have the following result

Result 5.2 The proportion of jobs that uses the PES procedure increase in bad aggregate conditions if the convolution $F_{X+Y}$ has a monotonic reverse hazard rate, or more formally if $\frac{f_{X+Y}(v)}{F_{X+Y}(v)}$ is monotonic in $v$.

Proof An increase in aggregate productivity is akin to an increase in $p$. We study the conditions under which $\frac{\partial \rho^{p e s}}{\partial p}<0$. Since $\frac{\partial \tilde{z}}{\partial p}=\frac{\partial z^{c t}}{\partial p}=-1$, simple algebra implies that

$$
\begin{gathered}
\frac{\partial \rho^{p e s}}{\partial p}=\frac{f_{X+Y}\left(z^{c t}\right)}{F_{X+Y}(\tilde{z})}-\frac{f_{X+Y}(\tilde{z})}{F_{X+Y}(\tilde{z})} \frac{F_{X+Y}\left(z^{c t}\right)}{F_{X+Y}(\tilde{z})} \\
=\frac{F_{X+Y}\left(z^{c t}\right)}{F_{X+Y}(\tilde{z})}\left[\frac{f_{X+Y}\left(z^{c t}\right.}{F_{X+Y}\left(z^{c t}\right)}-\frac{f_{X+Y}(\tilde{z})}{F_{X+Y}(\tilde{z})}\right]
\end{gathered}
$$

Since $z^{c t}<\tilde{z}$, monotonicity of the reverse hazard rate is a sufficient condition for the results that $\frac{\partial \rho^{p e s}}{\partial p}<0$.

In probability theory, the reverse hazard rate at $z$ is the probability of observing an outcome in the neighborhood of $z$ conditional on the outcome being no more than $z$. Ultimately, the shape of the convolution $F$ is an empirical question, but numerically an exponential distribution with parameter $\lambda<1$ satisfies the conditions of results.

\section{The Role of Financial Constraints}

Over and beyond the idea that the proportion $\rho^{\text {pes }}(p)$ depend on the statistical properties of $F_{X+Y}$, we consider the issue linked to the firm's financial situation during the dismissal 
procedure. The issue we want to consider is that job in dismissing procedure have negative economic value, since $J^{c t}(x+y)<J^{p e s}(x+y)<0 \forall(x+y)<x^{c t}+y^{c t}$. This suggests that the cash flow necessary to cover the economic loss can not come from internal funding.

In this section we assume that capital markets are imperfect, there is no funding for jobs in a dismissing procedure and funding comes from entrepreneur private funds. We shall indicate with $r Y_{0}(p)$ the present discounted value of such entrepreneur's funds. Let's define the cash flow at PES as the flow value generated by the match as

$$
C F^{\text {pes }}(x+y)=x+y+p
$$

while the cash flow generated by a court match is

$$
C F^{c t}(x+y)=x+y+p-s F
$$

Definition 6 A court job is cash constrained when $J^{c t}(x+y)>J^{p e s}(x+y)$ but $\mid C F^{c t}(x+$ $y) \mid>r Y_{0}(p)$

The definition highlights the possibility that a firm that would optimally choose to go to court faces cash constraint problems, since the flow cost is higher than their available resources.

If we assume that jobs differ in being cash constrained, then we have two straightforward results.

Result 5.3 There exist court jobs that are cash constraint and that, as a consequence, 
switch to PES.

The result is straightforward. As long as $F>0$ and the job space is complete, some of the court cases are forced to go to PES because of cash constraints.

Result 5.4 When aggregate time worsen, the share of cash constrained jobs increases and the share of jobs at PES raises relative to the court cases.

Note that our model is based on jobs rather than on well defined firms. As such, it can not rationalize the fact that PES is mainly used by small firms. Yet, the idea that financial constraints may bias the choice toward PES may well be related to the size result. It is empirically well established that financial constraints are more binding in small firms and start-ups, also in the Netherlands. Inasmuch as this is the case, the size bias toward the PES is likely to be associated to the cash story. Nevertheless, we do not have information on firms' financial conditions and we are not in a position to empirically check this claim.

\subsection{The Probability of Denial}

In recessions the volume of dismissal requests to the PES increases more than the volume of requests to the court. More surprisingly, however, is that the rate of rejections at the PES increases more also. Table 9 shows the percentages of dismissal requests that have been rejected through time. The period covered by the data includes the onset of the Great Recession. In 2009 the unemployment rate in the Netherlands rises markedly. The denial rate of dismissal requests increases at the same time. This result is entirely due 
to the substantially large increase of the rate of denial by the PES in 2009.

Cyclical dependence of court rulings on labor disputes have been studied before by Siegelman and Donohue (1995), Ichino et al. (2003), and Marinescu (2011), for example. Despite the - not so terribly convincing - evidence in these papers that court rulings may be cyclically biased, the results from our data do not show such a relationship between the decision of the court and the state of the economy at all. In fact, court denials remain constant across time and reasons, even in the first year of the Great Recession. The upsurge in the rate of denial in 2009 comes almost entirely from rejections by the PES of firm dominant dismissal requests, indeed. This finding suggests that in bad times PES requests are based more likely on insufficiently solid argumentation.

We estimate the likelihood that a dismissal request will be granted or not using a probit regression model, and find that when a process takes more time to decide the probability of approval declines. Results are presented in Table 10. Worker dominant reasons have a lower probability of being granted. Relevant predictors of a successful dismissal request are indeed the reason and the timing of the request. But adding more information about the specificity of the conflict reasons and why and when dismissal requests are filed leads to a diminished specificity of the role of the addressed institution.

Several reasons might explain why the PES denial rate rises in bad times. One possible explanation is that firms may be more financially constrained in recessions. The expected costs of a dismissal by court ruling exceed those of a PES approved job ending. In bad times, firms might think then that it is worth a shot, prefer time over money, and choose for the less costly alternative to obtain a lay-off permission, even if the expected duration 
is longer and the probability of success is lower when the reasoning is not sufficient. Another possible explanation is the prevalence of employer moral hazard in the labor market (cf. Gáldon-Sánchez and Güell (2003)). Employer moral hazard refers to those situations in which an employer wishes to shift private costs to society on considerations of self-interest alone. In bad times, some employers may want to reduce the size of their workforce while saving firing costs on unjustifiable grounds. The PES is expert in the identification of dismissal requests that are not based on justifiable grounds. The dual system of preventive dismissal checks reduces the efficacy of such behavior. If employer moral hazard in the labor market exists, then the PES shall receive more unjustified dismissal requests in recessions than in booms and, consequently, the denial rate will be counter-cyclical. Although being consistent with the results found, the information in our data-set does not allow us to precisely identify and let alone exactly estimate the importance of any of these considerations. However, we can state for certain that an increase in the denial rate of dismissal requests by the PES prevents workers to be displaced for unjustified reasons in recessions more often. Further research is needed to better understand how these mechanisms affect labor demand, unemployment and welfare in recessions.

\section{Concluding Remarks}

Dismissal conflicts are part of life of most labor markets. Yet, they are traditionally treated as a black box by empirical economists as well as by theoretical models of em- 
ployment protection legislation. This paper has opened the black box. Empirically, it exploited a unique data set with more than 2000 dismissal disputes that took place in the period between 2006 and 2009. We distinguished between firm and worker dominant cases depending upon which of the two parties can be empirically held more responsible for the disagreement over the employment termination. Naturally, we also account for difficult cases, disputes in which it is not obvious to establish a clear cut responsibility. Such classification is often used by existing institutions and is encoded in existing law. The paper showed that it is also coherent with a straightforward theory oriented taxonomy.

The Dutch labor market, the country in which our observed disputes took place, turned out to be home to a unique employment protection legislation. In the Netherlands, alongside a traditional court, firms are entitled to get firing permission by the Public Employment Service, an institution that was introduced during World War II and survived for 70 years. The unique feature is that PES dismissals can take place without severance payments and other mandated firing costs, provided the firm is willing to undertake a lengthy procedure and obtain formal authorization. Court ruling, conversely, is much quicker but much more expensive. An endogenous sorting between the two institutions emerge in the labor market, with worker dominant cases being examined proportionally more by the PES. Court ruling specializes in uncertain cases. Such endogenous sorting is coherent with a basic equilibrium model of firing restrictions that the paper proposed and solved. In the model, heterogeneous matches optimally weighs the trade off between a costly court ruling and a time consuming PES procedure. 
Dismissal disputes can be looked upon in many other dimensions. Depending on data availability, one could study which separations end up in a disputes and which cases are solved without third party involvement. The strategic behavior conducted by both firms and workers are other interesting dimensions to be investigated, particularly within imperfect information setting. This paper has opened the black box of dismissal disputes in some dimensions. Future studies and future data sets for more countries can certainly throw lights on other key dimensions. 


\section{References}

Acemoglu, Daron (2001), "Good Jobs versus Bad Jobs." Journal of Labor Economics, Vol.19, pp. 1-21.

Acemoglu, Daron, and Joshua Angrist (2001), "Consequences of Employment Protection? The Case of the Americans with Disabilities Act." Journal of Political Economy, Vol.109, pp. 915-957.

Alvarez, Fernando, and Marcelo Veracierto (2012), "Fixed-term Employment Contracts in an Equilibrium Search Model." Journal of Economic Theory, Vol. 147(5), pp. 1725-1753.

Autor, David H.; John J. Donohue III, and Stewart J. Schwab (2006). "The Costs of Wrongful Discharge Laws." The Review of Economics and Statistics, Vol. 88, pp. $211-231$.

Bender, Stefan, Christian Dustmann, David Margolis, and Costas Meghir (2002), "Worker Displacement in France and Germany."In Peter J. Kuhn (Ed.): Losing Work, Moving On: International Perspectives on Worker Displacement. W.E. Upjohn Institute for Employment Research, Kalamazoo (MI), pp. 375470.

Bentolila, Samuel, and Guiseppe Bertola (1990), "Firing Costs and Labour Demand: How Bad is Eurosclerosis?" Review of Economic Studies, Vol. 57, pp. 381-402.

Blanchard, Olivier , and Jean Tirole (2008), "The Joint Design of Unemployment Insurance and Employment Protection: A First Pass." Journal of the European Economic Association, Vol. 6(1), pp. 45-77.

Boeri, Tito; Pietro Garibaldi, and Espen Moen (2014), "Financial Constraints in Search Equilibrium."CEPR Discussion Paper 10266.

Boeri, Tito, and Juan F. Jimeno (2005), "The Effects of Employment Protection: Learning fromVariable Enforcement." European Economic Review, Vol.49, pp. 20572077.

Boeri, Tito, and Jan van Ours (2013), "The Economics of Imperfect Labor Markets." Second Edition. Princeton University Press.

Emerson, Michael (1988), "Regulation or Deregulation of the Labour Market: Policy Regimes for the Recruitment and Dismissal of Employees in Industrialised Countries." European Economic Review, Vol. 32(4), pp. 775-817.

Frenk, Myrthe (2013), "Job Security in the Netherlands."PhD-Thesis, Maastricht University. Available at: http://digitalarchive.maastrichtuniversity.nl/fedora/get/guid:6d70a3f3 d4eb-48b5-8536-840248787e70/ASSET1

Fuchs, Wliliam and Andrzei Skrzypacz (2013) "Bargaining with Deadlines and Private Information " American Economic Journal: Microeconomics 2013, 5(4): 219243

Gáldon-Sánchez, José E., and Maia Güell (2003), "Dismissal Conflicts and Unemployment." European Economic Review, Vol. 47, pp. 323-335. 
Garibaldi, Pietro (1998), "Job Flow Dynamics and Firing Restrictions." European Economic Review, Vol. 42(2), pp. 245-275.

Garibaldi, Pietro, and Giovanni L. Violante (2005), "The Employment Effects of Severance Payments with Wage Rigidities." Economic Journal, Vol. 115, pp. 799832.

Ichino, Andrea; Michele Polo, and Enrico Rettore (2003), "Are Judges Biased by Labor Market Conditions?" European Economic Review, Vol. 47(5), pp. 913-944.

Jacobs, Antoine T.J.M. (2004), "Part I. The Individual Employment Relationship and Labour Market Regulation."In Roger Blanpain (Ed.): International Encyclopaedia for Labour Law and Industrial Relations, Netherlands. Kluwer Publishers.

Kennan, John (1986), "The Economics of Strikes." In: Orley C. Ashenfelter and Richard Layard (Eds.) Handbook of Labor Economics, Vol. II, Chapter 19, pp. 1091-1137.

Kennan, John, and Robert Wilson "Bargaining with Private Information "Journal of Economic Literature Vol. XXX1 (march), pp. 45-104.

Koopmans, Tjalling C. (1947), "Measurement Without Theory." The Review of Economics and Statistics, Vol. 49(3), pp. 161-172.

Lazear, Edward P. (1990), "Job Security Provisions and Employment." The Quarterly Journal of Economics, Vol. 105(3), pp. 699-726.

Marinescu, Elena (2011), "Are Judges Sensitive to Economic Conditions? Evidence from UK Employment Tribunals." Industrial and Labor Relations Review, Vol. 64(4), pp. 673-698.

Millard, Stephen P., and Dale T. Mortensen (1997), "The Unemployment and Welfare Effects of Labor Market Policies: A Comparison of the USA and the UK."In Dennis J. Snower and Guillermo de la Dehesa (Eds.): Unemployment Policy: Government Options for the Labour Market. Cambridge University Press.

Nickell, Stephen J. (1978), "Fixed Costs, Employment and Labour Demand over the Cycle." Economica, Vol. 45, pp. 329-345.

Pfann, Gerard A. (2006), "Downsizing and Heterogeneous Firing Costs." The Review of Economics and Statistics, Vol. 88, pp. 158 - 170.

Ross, Sheldon M. (2002). "Introduction to Probability Models. Academic Press.

Saint-Paul, Gilles (1993). "On the Political Economy of Labor Market Flexibility, "NBER Chapters, in: NBER Macroeconomics Annual 1993, Volume 8, pages 151196 National Bureau of Economic Research, Inc.

Siegelman, Peter, and John J. Donohue III (1995), "The Selection of Employment Discrimination Disputes for Litigation: Using Business Cycle Effects to Test the Priest-Klein Hypothesis." Journal of Legal Studies, Vol.24, pp. 427-472. 


\section{Theoretical Annex}

The equilibrium exists and it is unique. in $\theta$

Proof. Using the fact that $\tilde{z}=r U(\theta)$ and $z^{c t}=r U-\frac{s^{c t} F\left(r+\delta+s^{p e s}\right)}{s^{c t}-s^{p e s}}$, equation 15 becomes an equatiion $\frac{c(r+\lambda+\delta)}{q(\theta)}=(\bar{x}+\bar{y})(1-\beta)-\beta c \theta+\lambda(1-\beta) \int_{r U(\theta)}^{z^{u}}\left(1-F_{X+Y}(m)\right) d m-\lambda(1+\beta) S^{c t}\left(\theta, z^{c t}\right)-\lambda(1+\beta) S^{p e s}\left(\theta, z^{c t}, \tilde{z}\right)$

The left hand side is increasing in $\theta$ since $q \prime(\theta)<0$. Differentiating the r.h.s with respect to $\theta$ yields

$$
\begin{gathered}
\frac{\partial J}{\partial \theta}=-\beta c-\lambda\left(1-F_{X+Y}(r U(\theta)) \frac{\partial r U}{\partial \theta}-\frac{\lambda(1+\beta)}{r+\lambda+\delta+s^{p e s}}\left[F_{X+Y}\left(r U^{c t}\right)-F_{X+Y}\left(z^{c t}\right)\right] \frac{\partial r U}{\partial \theta}\right. \\
-\frac{\lambda(1+\beta)}{r+\lambda+\delta+s^{c t}} F_{X+Y}\left(z^{c t}(\theta)\right) \frac{\partial r U}{\partial \theta}<0
\end{gathered}
$$

where the negative slope depends on the fact that $r U=b+c \theta \frac{\beta}{1-\beta}$ so that $\frac{\partial r U}{\partial \theta}>0$

\section{Balance Flow Conditions}

To obtain the balance flow we need some accounting and definitions. Let's say that the total number of jobs is $n$, a variable that will be endogenous in general equilibrium. It is true that

$$
n=n^{g}+n^{p e s}+n^{c t}
$$

where $n^{g}, n^{\text {pes }}$ and $n^{c t}$ are the number of jobs in good conditions, in PES procedure and in court ruling. The measure of jobs that is seeking a permision to fire is

$$
\text { Total jobs willing to separate }=\lambda F_{X+Y}(\tilde{z}) n^{g}
$$

where $F_{X+Y}$ is the convolution of $X$ and $Y$ and $\tilde{z}=\tilde{x}+\tilde{y}$ is the marginal good job of equation (8). Similarly, the applications to the court are

$$
\text { Applications to Court permissions }=\lambda F_{X+Y}\left(z^{c t}\right) n^{g}
$$

where $z^{c t}$ is the marginal court job. Finally, the applications to the PES offices are

$$
\text { Applications to PES permissions }=\lambda\left(F_{X+Y}\left(\tilde{z}-z^{c t}\right)\right) n^{g}
$$

The unemployment flow condition is $\theta q(\theta) u=s^{p e s} n^{\text {pes }}+s^{c t} n^{c t}$, while the balance flows in the two intitutions are respectively governed by

$$
\lambda F_{X+Y}\left(z^{c t}\right) n^{g}=s^{c t} n^{c t}
$$

and

$$
\lambda\left(F_{X+Y}\left(\tilde{z}-z^{c t}\right)\right) n^{g}=s^{p e s} n^{p e s} .
$$




\section{TABLES}

Table 1: Sorting By Reasons for Dismissal Requests

\begin{tabular}{|c|c|c|c|c|}
\hline Reasons: & $\begin{array}{c}\text { Worker Dominant } \\
x<0 \text { and } y>0\end{array}$ & $\begin{array}{l}\text { Firm Dominant } \\
x>0 \text { and } y<0\end{array}$ & $\begin{array}{c}\text { Both-to-blame } \\
x<0 \text { and } y<0\end{array}$ & $\begin{array}{c}\text { All } \\
\text { Reasons }\end{array}$ \\
\hline $\begin{array}{l}\text { COURT } \\
\text { \# of obs. } \\
\% \text { of COURT obs. } \\
\% \text { of } A L L \text { obs. }\end{array}$ & $\begin{array}{l}77 \\
7.5 \\
3.5\end{array}$ & $\begin{array}{l}242 \\
23.5 \\
11.0\end{array}$ & $\begin{array}{l}710 \\
69.0 \\
32.4\end{array}$ & $\begin{array}{c}\mathbf{1 , 0 2 9} \\
100.0 \\
47.0\end{array}$ \\
\hline $\begin{array}{l}\text { PES } \\
\text { \# of obs. } \\
\% \text { of PES obs. } \\
\% \text { of } A L L \text { obs. }\end{array}$ & $\begin{array}{l}309 \\
26.6 \\
14.1\end{array}$ & $\begin{array}{l}843 \\
72.5 \\
38.5\end{array}$ & $\begin{array}{l}\mathbf{1 0} \\
0.9 \\
0.5\end{array}$ & $\begin{array}{c}\mathbf{1 , 1 6 2} \\
100.0 \\
53.0\end{array}$ \\
\hline $\begin{array}{l}\text { COURT \& PES } \\
\text { \# of obs. } \\
\% \text { of } A L L \text { obs. }\end{array}$ & $\begin{array}{l}386 \\
17.6\end{array}$ & $\begin{array}{c}1,085 \\
49.5\end{array}$ & $\begin{array}{l}720 \\
32.9\end{array}$ & $\begin{array}{r}2,191 \\
100.0\end{array}$ \\
\hline $\begin{array}{l}\text { Notes: Worker domina } \\
\text { sickness; disciplinary r } \\
\text { Firm dominant reasons } \\
\text { those cases where it is } \\
\text { These include fairness } \\
\text { employer. }\end{array}$ & $\begin{array}{l}\text { reasons for requesting } \\
\text { sons related to condu } \\
\text { clude redundancy, rel } \\
\text { ubtful which party is } \\
\text { ues, disputes and oth }\end{array}$ & $\begin{array}{l}\text { a dismissal include ab } \\
\text { t, ability or capabilit } \\
\text { cation or reorganizati } \\
\text { esponsible most for m } \\
\text { r disturbed relationsh }\end{array}$ & $\begin{array}{l}\text { ence from work due to } \\
\text { and other substanti } \\
\text {; Both-to-blame reas } \\
\text { king the separation c } \\
\text { ps between an emplo }\end{array}$ & $\begin{array}{l}\text { long-term } \\
\text { al reasons; } \\
\text { ons contain } \\
\text { ompulsory. } \\
\text { yee and an }\end{array}$ \\
\hline
\end{tabular}


Table 2: Summary Statistics of Dismissal Requests During The Period 2006 - 2009

\begin{tabular}{|c|c|c|c|c|c|c|}
\hline $\begin{array}{l}\text { COURT } \\
\text { \# obs: } 1,029\end{array}$ & $\begin{array}{l}\text { Duration } \\
\text { (in days) }\end{array}$ & $\begin{array}{c}\text { Tenure } \\
\text { (in years) }\end{array}$ & $\begin{array}{c}\text { Age } \\
\text { (in years) }\end{array}$ & $\begin{array}{c}\text { Gender } \\
\left(q=0 ; \sigma^{\top}=1\right)\end{array}$ & $\begin{array}{l}\text { Hourly wage } \\
(\text { in } 2006 €)\end{array}$ & $\begin{array}{c}\text { Hours } \\
\text { worked }\end{array}$ \\
\hline mean & 11.17 & 9.84 & 42.20 & .63 & 16.23 & 33.55 \\
\hline st.dev. & 19.28 & 9.60 & 10.01 & .48 & 8.49 & 7.78 \\
\hline $1 \%$ percentile & 0 & .30 & 22 & 0 & 7.53 & 8.00 \\
\hline $50 \%$ percentile & 3 & 6.45 & 42 & 1 & 13.91 & 36.10 \\
\hline $99 \%$ percentile & 76 & 40.35 & 62 & 1 & 47.42 & 42.99 \\
\hline $\begin{array}{l}\text { PES } \\
\text { \# obs: } 1,162\end{array}$ & $\begin{array}{l}\text { Duration } \\
\text { (in days) }\end{array}$ & $\begin{array}{c}\text { Tenure } \\
\text { (in years) }\end{array}$ & $\begin{array}{c}\text { Age } \\
\text { (in years) }\end{array}$ & $\begin{array}{c}\text { Gender } \\
\left(q=0 ; \sigma^{\top}=1\right)\end{array}$ & $\begin{array}{l}\text { Hourly wage } \\
\text { (in } 2006 € \text { ) }\end{array}$ & $\begin{array}{c}\text { Hours } \\
\text { worked }\end{array}$ \\
\hline mean & 42.20 & 10.82 & 44.45 & .60 & 13.46 & 31.79 \\
\hline st.dev. & 32.52 & 8.77 & 10.11 & .49 & 5.22 & 9.85 \\
\hline $1 \%$ percentile & 1 & .31 & 22 & 0 & 7.82 & 5.24 \\
\hline $50 \%$ percentile & 36 & 7.79 & 45 & 1 & 12.35 & 36.41 \\
\hline $99 \%$ percentile & 167 & 36.52 & 63 & 1 & 32.18 & 40.67 \\
\hline mean difference & -31.03 & -.99 & -2.24 & .03 & 2.77 & 1.77 \\
\hline$t-t e s t^{\dagger}$ & -27.52 & -2.50 & -5.21 & 1.60 & 9.08 & 4.69 \\
\hline$p$-value & .00 & .01 & .00 & .11 & .00 & .00 \\
\hline
\end{tabular}

${ }^{\dagger}$ Two-sample $t$-test with unequal variances.

Notes: Duration is defined as the time in days that passes between the submission of a permanent contract termination request and the final ruling; tenure is the time that a worker is employed measured in years at the moment of request submission; age of a worker is measured in years at the moment of request submission; hourly wage is the contract wage per hour worked measured in $2006 €$ at the time of request submission excl. bonuses, holiday payments, and other fees. Hours worked is contract working hours per week 
Table 3: Duration Differences By Reasons for Dismissal Requests

\begin{tabular}{lccc}
\hline \hline Reasons: & $\begin{array}{c}\text { Worker Dominant } \\
x<0 \text { and } y>0\end{array}$ & $\begin{array}{c}\text { Firm Dominant } \\
x>0 \text { and } y<0\end{array}$ & $\begin{array}{c}\text { Both-to-blame } \\
x<0 \text { and } y<0\end{array}$ \\
\hline COURT & 33.23 & 10.39 & 9.04 \\
$($ st.dev. $)$ & $(3.93)$ & $(1.19)$ & $(.58)$ \\
\hline & & & \\
PES & 57.78 & 36.44 & 46.40 \\
$($ st.dev. $)$ & $(2.91)$ & $(.67)$ & $(7.98)$ \\
& & & -37.36 \\
Difference & -24.55 & -26.05 & .00 \\
p-value & .00 & .00 & \\
\hline \hline
\end{tabular}

†Two-sample $t$-test with unequal variances.

Table 4: Duration Differences By Employer Size

\begin{tabular}{lccc}
\hline \hline Employer Size & $0-9$ & $10-99$ & $\geq 100$ \\
& & & \\
\hline COURT & 13.88 & 12.56 & 9.68 \\
(st.dev. & $(1.45)$ & $(1.09)$ & $(.82)$ \\
\# of obs. & 166 & 291 & 572 \\
\% of obs. & 16.1 & 28.3 & 55.6 \\
& & & \\
\hline & & & \\
PES & 35.89 & 42.81 & 46.07 \\
(st.dev. & $(1.45)$ & $(1.28)$ & $(2.31)$ \\
\# of obs. & 224 & 681 & 257 \\
\% of obs. & 19.3 & 58.6 & 22.1 \\
& & & \\
\hline & & & \\
Difference & -22.02 & -30.25 & -36.40 \\
p-value & .00 & .00 & .00 \\
& & & \\
\hline \hline
\end{tabular}

$\overline{{ }^{\dagger} \text { Two-sample } t \text {-test with unequal variances. }}$ 


\begin{tabular}{|c|c|c|}
\hline & \multicolumn{2}{|c|}{$\begin{array}{c}\text { Dependent Variable: } \\
\text { Procedural Duration in Days }\end{array}$} \\
\hline & Baseline Model & Extended Model \\
\hline Constant & $\begin{array}{l}9.04^{* * *} \\
(.972)\end{array}$ & $\begin{array}{l}-13.55^{*} \\
(8.09)\end{array}$ \\
\hline $\mathrm{X}(x>0)$ & $\begin{array}{l}1.35 \\
(1.93)\end{array}$ & $\begin{array}{l}.745 \\
(1.95)\end{array}$ \\
\hline $\mathrm{Y}(y>0)$ & $\begin{array}{c}24.18^{* * *} \\
(3.11)\end{array}$ & $\begin{array}{c}24.09^{* * *} \\
(3.12)\end{array}$ \\
\hline PES & $\begin{array}{c}26.05^{* * *} \\
(1.89)\end{array}$ & $\begin{array}{c}25.48^{* * *} \\
(1.99)\end{array}$ \\
\hline PES*Y & $\begin{array}{l}-1.50 \\
(3.80)\end{array}$ & $\begin{array}{l}-.959 \\
(3.86)\end{array}$ \\
\hline Worker characteristics ${ }^{1}$ & No & \\
\hline Age & & $\begin{array}{l}.036 \\
(.065)\end{array}$ \\
\hline Tenure & & $\begin{array}{l}.085 \\
(.072)\end{array}$ \\
\hline Male & & $\begin{array}{l}-1.47 \\
(1.47)\end{array}$ \\
\hline Hours & & $\begin{array}{l}.177^{* *} \\
(.083)\end{array}$ \\
\hline Wage & & $\begin{array}{l}.172^{* *} \\
(.088)\end{array}$ \\
\hline Firm characteristics ${ }^{2}$ & No & \\
\hline Firm Size: Small: $\quad<10 \quad$ employees & & $\begin{array}{l}1.109 \\
(1.80)\end{array}$ \\
\hline Firm Size: Medium: [10;100] employees & & $\begin{array}{l}2.277^{*} \\
(1.39)\end{array}$ \\
\hline Industry dummies & No & Yes \\
\hline Monthly unemployment rate ${ }^{3}$ & No & Yes \\
\hline $\begin{array}{l}\# \text { of obs. } \\
R^{2}\end{array}$ & $\begin{array}{r}2181 \\
.313\end{array}$ & $\begin{array}{l}2181 \\
.326\end{array}$ \\
\hline
\end{tabular}

Notes: Robust standard errors are reported in parentheses. ${ }^{*} p<.10,{ }^{* *} p<.05,{ }^{* * *} p<.01$. Process duration is defined as the time in days that passes between the submission of a permanent contract termination request and the final ruling. ${ }^{1}$ Tenure is the time that a worker is employed measured in years at the moment of request submission; Age of a worker is measured in years at the moment of request submission; Wage is 5 he contract wage per hour worked measured in $2006 €$ at the time of request submission excl. bonuses, holiday payments, and other fees. Hours worked is contract working hours per week. ${ }^{2}$ Reference category is large firms with more than 100 employees. ${ }^{3}$ The monthly unemployment rate is a business cycle indicator for the Netherlands' economy. The 10 observations for PES with $\mathrm{x}>0$ and $\mathrm{y}<0$ are not included in the regression. 
Table 6: Institutional Biases

Dependent Variable:

Process Duration in Days

\begin{tabular}{|c|c|}
\hline Constant & $\begin{array}{l}-2.05 \\
(9.05)\end{array}$ \\
\hline $\mathrm{X}(x>0)$ & $\begin{array}{l}1.08 \\
(1.95)\end{array}$ \\
\hline $\mathrm{Y}(y>0)$ & $\begin{array}{c}23.38^{* * *} \\
(3.10)\end{array}$ \\
\hline PES & $\begin{array}{c}5.01 \\
(7.50)\end{array}$ \\
\hline PES*Y & $\begin{array}{c}.717 \\
(3.81)\end{array}$ \\
\hline \multicolumn{2}{|l|}{ Interaction effects } \\
\hline PES*Age & $\begin{array}{l}-.184 \\
(.129)\end{array}$ \\
\hline PES*Tenure & $\begin{array}{l}.135 \\
(.137)\end{array}$ \\
\hline PES*Male & $\begin{array}{c}-9.68^{* * *} \\
(2.91)\end{array}$ \\
\hline PES*Hours & $\begin{array}{l}.646^{* * *} \\
(.167)\end{array}$ \\
\hline PES*Wage & $\begin{array}{l}.810^{* * *} \\
(.188)\end{array}$ \\
\hline Worker characteristics & Yes \\
\hline Firm characteristics & Yes \\
\hline Monthly unemployment rate & Yes \\
\hline $\begin{array}{l}\# \text { of obs. } \\
R^{2}\end{array}$ & $\begin{array}{r}2181 \\
.339\end{array}$ \\
\hline
\end{tabular}

Notes: Robust standard errors are reported in parentheses. ${ }^{*} p<.10$, ${ }^{* *} p<.05,{ }^{* * *} p<.01$. Process duration is defined as the time in days that passes between the submission of a permanent contract termination request and the final ruling. The 10 observations for PES with $\mathrm{x}>0$ and $\mathrm{y}<0$ are not included in the regression. 
Table 7: Procedural Outcomes of Dismissal Requests

\section{Court Rulings on Dismissal Requests}

Reasons: $\quad$ Worker Dominant Firm Dominant Both-to-blame

Granted:

$\begin{array}{lccl}\text { Duration } & 32.61 & 9.55 & 7.94 \\ \text { \# of obs. } & 48 & 233 & 671\end{array}$

Denied:

$\begin{array}{lccc}\text { Duration } & 34.25 & 32.16 & 28.06 \\ \text { \# of obs. } & 29 & 9 & 39\end{array}$

Difference

$-1.63$

$-22.61$

$-20.12$

p-value

.81

.01

.00

\section{PES Decisions on Dismissal Requests}

Reasons: $\quad$ Worker Dominant Firm Dominant Both-to-blame

Granted:

$\begin{array}{lccc}\text { Duration } & 58.21 & 36.50 & 24.00 \\ \text { \# of obs. } & 274 & 742 & 2\end{array}$

Denied:

$\begin{array}{lccc}\text { Duration } & 54.4 & 36.01 & 52.00 \\ \text { \# of obs. } & 35 & 101 & 8\end{array}$

Difference

3.81

.49

$-28.00$

p-value

.65

.83

.31

†Two-sample t-test with unequal variances. 


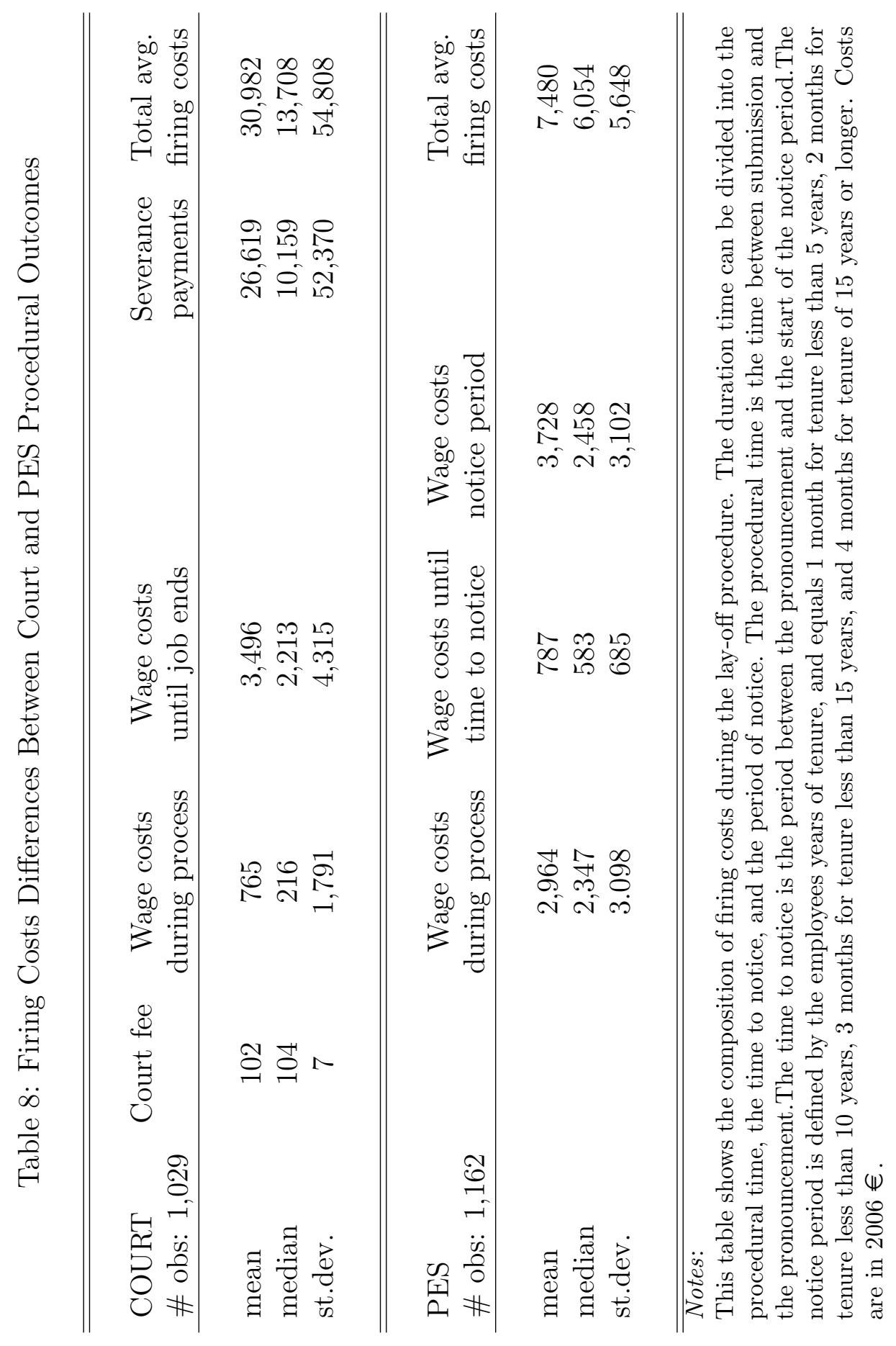


Table 9: Denied Dismissal Requests Over Time ${ }^{\dagger}$

\begin{tabular}{lccccc}
\hline \hline Reasons: & $\begin{array}{c}\text { Worker } \\
\text { Dominant }\end{array}$ & $\begin{array}{c}\text { Firm } \\
\text { Dominant }\end{array}$ & Both-to-blame & ALL & $\Delta(U \text {-Rate })^{1}$ \\
2006 & 17.0 & 7.18 & 7.17 & 8.59 & -1.0 \\
COURT & 9.44 & 1.10 & 6.04 & 4.09 & \\
PES & 7.56 & 6.08 & 1.13 & 4.50 & \\
& & & & & \\
2007 & 16.4 & 8.47 & 4.68 & 8.94 & -1.0 \\
COURT & 5.45 & 1.06 & 4.09 & 3.19 & \\
PES & 10.9 & 7.41 & 0.59 & 5.74 & -0.6 \\
2008 & 14.1 & 6.37 & 8.61 & 9.00 & \\
COURT & 6.52 & 0.0 & 6.62 & 4.00 & +0.9 \\
PES & 7.61 & 6.37 & 1.99 & 5.00 & \\
2009 & 19.2 & 15.4 & 5.30 & 13.6 & \\
COURT & 8.97 & 0.80 & 4.54 & 2.73 & \\
PES & 10.2 & 14.6 & 0.76 & 10.9 & \\
\hline \hline
\end{tabular}

${ }^{\dagger}$ In percentages of total number of requests per reason per year.

${ }^{1} \Delta$ (U-Rate) is the change in the annual unemployment rate compared to the previous year. 
Table 10: Determinants of the Likelihood Dismissal Requests Are Granted or Denied

\section{Dependent Variable}

Procedural Outcome: $1=$ Granted ; $0=$ Denied

\begin{tabular}{|c|c|c|c|c|c|}
\hline Model: & Probit & Probit & Probit & Probit & Probit \\
\hline Constant & $\begin{array}{c}-1.440^{* * *} \\
(.058)\end{array}$ & $\begin{array}{c}1.504^{* * *} \\
(.061)\end{array}$ & $\begin{array}{c}1.212^{* * *} \\
(.119)\end{array}$ & $\begin{array}{c}1.242^{* * *} \\
(.131)\end{array}$ & $\begin{array}{c}1.640^{* * *} \\
(.583)\end{array}$ \\
\hline PES & $\begin{array}{c}-.285^{* * *} \\
(.075)\end{array}$ & $\begin{array}{l}-.163^{*} \\
(.082)\end{array}$ & $\begin{array}{c}-.090 \\
(.109)\end{array}$ & $\begin{array}{l}-.066 \\
(.110)\end{array}$ & $\begin{array}{l}.001 \\
(.119)\end{array}$ \\
\hline Process Duration & & $\begin{array}{c}-.004^{* * *} \\
(.001)\end{array}$ & $\begin{array}{c}-.003^{* * *} \\
(.001)\end{array}$ & $\begin{array}{c}-.003^{* * *} \\
(.001)\end{array}$ & $\begin{array}{c}-.004^{* * *} \\
(.001)\end{array}$ \\
\hline \multicolumn{6}{|l|}{ Reasons $^{1}$} \\
\hline Firm dominant & & & $\begin{array}{l}.237^{* *} \\
\left(.09^{r}\right)\end{array}$ & $\begin{array}{l}.285^{* * *} \\
(.099)\end{array}$ & $\begin{array}{l}225^{* *} \\
(.105)\end{array}$ \\
\hline Both-to-blame & & & $\begin{array}{l}.346^{* * *} \\
(.133)\end{array}$ & $\begin{array}{l}.359^{* * *} \\
(.134)\end{array}$ & $\begin{array}{l}.376^{* * *} \\
(.137)\end{array}$ \\
\hline \multicolumn{6}{|l|}{ Year $^{2}$} \\
\hline 2007 & & & & $\begin{array}{l}.015 \\
(.107)\end{array}$ & $\begin{array}{l}.052 \\
(.111)\end{array}$ \\
\hline 2008 & & & & $\begin{array}{c}.001 \\
(.112)\end{array}$ & $\begin{array}{c}.079 \\
(.117)\end{array}$ \\
\hline 2009 & & & & $\begin{array}{c}-.247^{* * *} \\
(.095)\end{array}$ & $\begin{array}{c}-.226^{* * *} \\
(.100)\end{array}$ \\
\hline Worker characteristics ${ }^{3}$ & No & No & No & No & Yes \\
\hline Firm characteristics ${ }^{4}$ & No & No & No & No & Yes \\
\hline $\begin{array}{l}\chi^{2}-t e s t \\
(d f)^{5} \\
p \text {-value }\end{array}$ & & $\begin{array}{c}13.72 \\
(1) \\
000\end{array}$ & $\begin{array}{c}8.63 \\
(2) \\
013\end{array}$ & $\begin{array}{l}9.58 \\
(3) \\
0.3\end{array}$ & $\begin{array}{c}33.78 \\
(19) \\
090\end{array}$ \\
\hline p-value & & & & & \\
\hline \# of obs. & 2190 & 2190 & 2190 & 2190 & $2178^{6}$ \\
\hline Pseudo $-R^{2}$ & .010 & .019 & .025 & .032 & .057 \\
\hline \multicolumn{6}{|c|}{$\begin{array}{l}\text { Notes: Standard errors are reported in parentheses. }{ }^{*} p<.10,{ }^{* *} p<.05,{ }^{* * *} p<.01 \text {. } \\
{ }^{1} \text { Reference category is Worker dominant: } x<0 ; y>0 .{ }^{2} \text { Reference year is } 2006 .{ }^{3} \text { Worker } \\
\text { characteristics include tenure, age, hourly wage, and hours worked. }{ }^{4} \text { Firm characteristics } \\
\text { include SBI and firm size indicators. }{ }^{5} \text { The } \chi^{2} \text { statistic reports the test value of the additional } \\
\text { variables added to the regression model, with } d f \text { is the number of variables added. }{ }^{6} \mathrm{~A} \text { total } \\
\text { of } 12 \text { cases dropped out of the regression due to perfect fit to two SBI categories. }\end{array}$} \\
\hline
\end{tabular}

